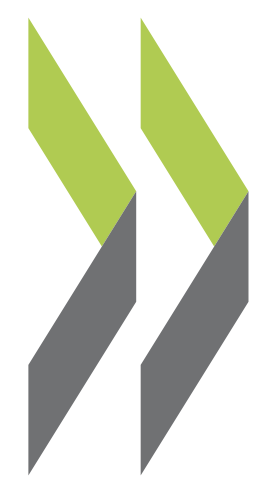

OECD Economics Department Working Papers No. 642

Isabelle Joumard,

Accounting for One-off

Operations when Assessing

Makoto Minegishi,

Christophe André,

Underlying Fiscal Positions

Chantal Nicq,

Robert Price 
Organisation de Coopération et de Développement Économiques

Organisation for Economic Co-operation and Development

30-Sep-2008

ECONOMICS DEPARTMENT

English text only

ACCOUNTING FOR ONE-OFF OPERATIONS WHEN ASSESSING UNDERLYING FISCAL POSITIONS

ECONOMICS DEPARTMENT WORKING PAPERS No. 642

By

Isabelle Joumard, Makoto Minegishi, Christophe André, Chantal Nicq and Robert Price

All Economics Department Working Papers are available through the OECD's internet web site at www.oecd.org/Working_Papers

JT03251553

Document complet disponible sur OLIS dans son format d'origine

Complete document available on OLIS in its original format 


\section{ABSTRACT/RÉSUMÉ}

\section{Accounting for one-off operations when assessing underlying fiscal positions}

Frequent recourse to large one-off operations in a number of OECD countries has undermined the accuracy of cyclically adjusted fiscal balances as a measure of both the sustainability of public finance and the fiscal stance. This paper first provides detailed information on the nature and amount of these one-offs for 9 OECD countries. The paper then presents a new indicator - the "underlying" fiscal balance - which effectively eliminates the impact of one-offs and cyclical developments. One-offs are derived as the deviations from trend in net capital transfers, i.e. from widely available national account data. This approach provides a consistent treatment of one-offs both across countries and over time, avoiding the potential information biases which could result from an individual identification of one-offs.

JEL classification: E62, H30, H60

Keywords: One-off fiscal operations; fiscal balances; cyclically adjusted fiscal balances; underlying fiscal balances; capital transfers.

$* * * * *$

\section{Évaluer les positions budgétaires sous-jacentes en présence de mesures ponctuelles}

Le recours fréquent à des mesures ponctuelles dans certains pays de l'OCDE a rendu caduque l'utilisation du solde budgétaire corrigé des variations cycliques pour évaluer tant la soutenabilité des finances publiques que l'impact des politiques budgétaires discrétionnaires sur l'activité économique. Ce document présente des informations détaillées sur la nature et le montant de ces mesures ponctuelles pour 9 pays de l'OCDE. Il propose ensuite un nouvel indicateur - le solde budgétaire sous-jacent - qui corrige le solde budgétaire des effets des mesures ponctuelles et du cycle économique. Les mesures ponctuelles sont assimilées aux écarts à la tendance des transferts en capitaux, séries facilement disponibles dans les comptes nationaux. Cette approche assure un traitement symétrique tant entre les pays qu'au cours du temps, évitant ainsi les biais potentiels qui découleraient d'une identification individuelle des mesures ponctuelles.

Classification JEL : E62, H30, H60

Mot clés: Mesures budgétaires ponctuelles; solde budgétaire; solde budgétaire corrigé des variations cycliques; solde budgétaire sous-jacent; transferts en capital.

\section{Copyright OECD, 2008}

Applications for permission to reproduce or translate all, or part of, this material should be made to: Head of Publications Service, OECD, 2 rue André-Pascal, 75775 Paris Cedex 16, France. 


\section{TABLE OF CONTENTS}

\section{ACCOUNTING FOR ONE-OFF OPERATIONS WHEN ASSESSING UNDERLYING FISCAL POSITIONS

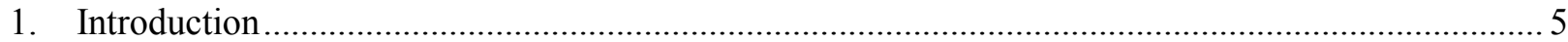

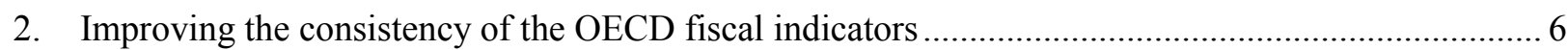

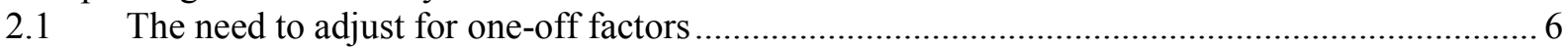

2.2 Problems with the previous treatment of one-offs ...................................................... 7

3. Difficulties of an approach based on an individual identification of one-offs .................................. 8

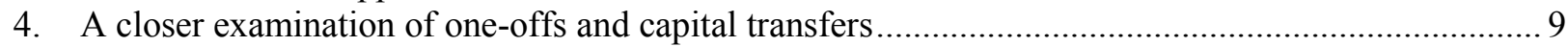

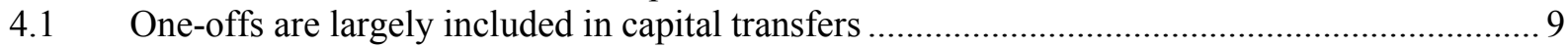

4.2 Cross-country differences in levels and trends of net capital transfers ................................... 13

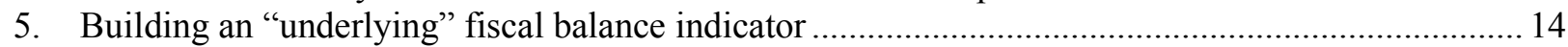

5.1 Filtering net capital transfers to identify and remove one-offs ............................................. 19

5.2 Implementing an "underlying" fiscal balance indicator.......................................................... 19

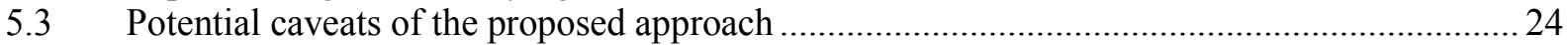

5.4 Comparing underlying balances with two different approaches for measuring one-offs ......... 25

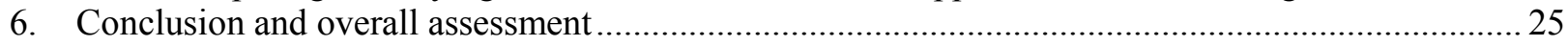

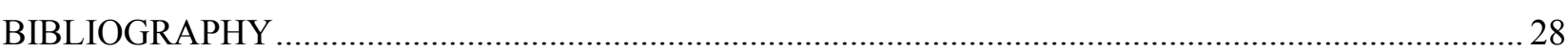

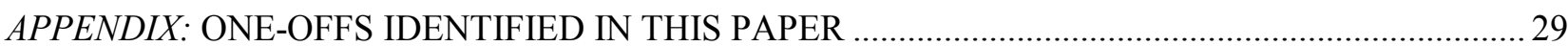

\section{Boxes}

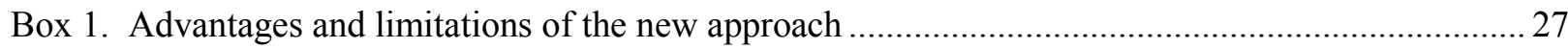

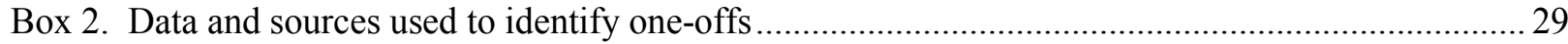

\section{Tables}

1. Current treatment of one-offs on the OECD Economic Outlook database

2. Examples of one-offs affecting balances through net capital transfers

3. Net capital transfers: major components

\section{Figures}

1. Level and composition of one-offs affecting fiscal balances for selected OECD coutnries

2. Net capital transfers and one-offs for selected OECD countries

3. Level and trend in capital transfers

4. Headline, cyclically-adjusted and underlyng fiscal balances

5. Comparing underlying balances with two different approaches for measuring one-offs 
ECO/WKP(2008)50 
ECO/WKP(2008)50

\title{
ACCOUNTING FOR ONE-OFF OPERATIONS WHEN ASSESSING UNDERLYING FISCAL POSITIONS
}

\author{
Isabelle Joumard, Makoto Minegishi, Christophe André, Chantal Nicq and Robert Price ${ }^{1}$
}

\section{Introduction}

1. Headline fiscal balances often reflect large and non-recurrent fiscal operations ("one-offs"). Typical examples include government sales of mobile phone licences, lump-sum payments to the government in exchange for the transfer of employees' pension obligations debt assumptions and tax amnesties. Over the past decade these have often led to sizeable, but temporary, shifts in fiscal balances, sometimes by more than several percentage points of GDP. In the process, fiscal one-offs have undermined the accuracy of cyclically adjusted fiscal balances as a measure of both fiscal sustainability and discretionary fiscal stance.

2. Fiscal balances published by the OECD in its biannual OECD Economic Outlook, up to the 83rd edition (June 2008), have been adjusted for one-offs where possible, but the treatment has been limited in scope and has lacked consistency. This paper presents a methodology for a more systematic treatment of one-offs which will be implemented from the $84^{\text {th }}$ edition of the OECD Economic Outlook. It relies on widely available national accounts data for net capital transfers to derive a proxy for one-offs - more specifically, the deviation of government net capital transfers from trend. Such an approach is supported by the results of a case study covering nine OECD countries which shows that most one-off operations are recorded as capital transfers. It offers a consistent treatment both across countries and over time, an objective which would be difficult to achieve via a process which relied on the individual identification of one-offs, given the inherent complexity and incompleteness of the information available.

3. The paper first discusses the need for improving fiscal sustainability and fiscal stance indicators and why the identification of one-offs may be useful in this respect. The previous treatment of one-offs is then reviewed, highlighting the problems of scope and consistency it raises. After examining the difficulties of an approach based on an individual identification of one-offs, national accounts data on capital transfers are examined in depth, with a particular focus on their relationship with identifiable oneoffs. Subsequently, an "underlying" fiscal balance indicator - the general government balance adjusted for

1. The authors are members and head of the Monetary and Fiscal Policy Division respectively. They are grateful to Jørgen Elmeskøv, Vincent Koen, Jean-Luc Schneider and other colleagues of the Economics Department for their comments and suggestions. They would also like to thank Lucio Pench, Paul van den Noord, Gerrit Bethuyne and Charlotte Van Hooydonk, from the European Commission, for kindly sharing their experience on this issue, and Véronica Humi and Susan Gascard for secretarial assistance. Any remaining errors fall under the responsibility of the authors. 
cyclical fluctuations and one-offs - is presented. The paper concludes with an overall assessment of the advantages and limitations of the new procedure.

\section{Improving the consistency of the OECD fiscal indicators}

\subsection{The need to adjust for one-off factors}

4. The OECD fiscal indicators, as published in the OECD Economic Outlook, were developed to serve two distinct purposes. ${ }^{2}$ By eliminating the impact of automatic stabilisers, changes in the cyclically adjusted budget balance can be interpreted as an indicator of discretionary shifts in fiscal stance. ${ }^{3}$ By eliminating the fiscal effects of the cycle, the cyclically adjusted budget balance also provides, in levels form, a measure of the structural, or underlying, budget balance, which is more relevant than the headline balance for medium-term fiscal planning, over which horizon output gaps are set to zero. In that respect, underlying balance is the concept most relevant to fiscal sustainability, defined in terms of the level to which the debt/GDP ratio converges given the potential growth rate of the economy. ${ }^{4}$

5. In practice, the use of cyclically adjusted fiscal balances as indicators of the structural budget balance has suffered from the fact that factors other than cyclical fluctuations in GDP can have a large transitory impact on fiscal balances. First, asset and commodity cycles may have a significant impact on the fiscal balances which are not adjusted for (Girouard and Price, 2004; Turner, 2006). ${ }^{5}$ The recent episodes of buoyant tax revenues resulting from higher asset/commodity prices in several OECD countries underscore the importance of this factor in assessing fiscal positions. Second, the cyclically adjusted balance has been occasionally affected by large non-recurrent fiscal operations with no implication for fiscal sustainability and at best very limited impact on economic activity - hereafter those operations will be referred to as "one-offs" or "one-off operations".

6. A typically characteristic of one-offs is that their impacts on fiscal balances are disproportionally large in the year when the operations are conducted, with subsequent yearly impact either nil or far smaller. Their longer-term effects sometimes run in the opposite direction: in the extreme case, the short-term impacts will eventually be nullified. As an illustration, lump-sum payments to the general government in exchange for the transfer of pension obligations will usually be reflected in a deterioration of fiscal balances when pension rights are eventually claimed, to the point that the initial gains will be completely

2. See Price and Muller (1984) and Chouraqui, Hagemann and Sartor (1990) for a description of the rationales.

3. Fiscal balances used in this paper are on a national account basis for the consolidated general government sector. They are based on accrual principle and only those factors that have impacts on fiscal balances ("above-the-line") are taken into account. There are other fiscal operations, such as financial transactions (treated "below-the-line") or off-budget items (contingent liabilities etc.) that are quite important for the assessment of fiscal positions, not least because they affect debt and/or have longer-term implications.

4. In practice, the issue of fiscal sustainability revolves around the level of future primary budget surpluses required to stabilise the debt ratio, which critically depends on the relative values of the nominal implicit interest rate on public debt and the nominal growth rate (Blanchard, 1990). Since gross debt accumulation may be more relevant from a financial point of view, it may be more appropriate to focus on government borrowing requirement, which includes borrowing to finance financial transactions, than on the structural/underlying fiscal balance. In that case, it would be useful to focus on the balance sheet of the government in assessing implication for fiscal sustainability (Milesi-Ferretti and Moriyama 2004).

5. While off-shore oil revenue of Norway has been taken out in the OECD cyclically adjusted balances, no adjustments have been made neither for other commodity-producing countries (e.g. Australia) nor asset price fluctuations. 
offset. Thus, from the sustainability viewpoint, any immediate impacts of one-offs should be heavily discounted when assessing fiscal positions.

7. Impacts of one-offs on short-term demand are less clear-cut, as some non-recurrent fiscal operations may have a clear short-term demand impact. However, as the following sections of the paper illustrate, short-term demand weight of many non-recurrent operations is likely to be very small or quite limited at best, given the financial nature of the transactions involved. As an instance, the mere transfer of asset and pension obligations from the private sector to the government is unlikely to have a major impact on real activity - thus it would be misguided to consider improved balance due to this factor as a meaningful change in fiscal stance. A further example is tax amnesties: although this operation tends to result in a non-negligible revenue increase in the very short-term, its long-term effects on fiscal sustainability is indirect through broadened tax base and better tax compliance and are quite uncertain ${ }^{6}$, particularly when amnesties are granted repeatedly. Other things being equal, debt assumptions or cancellations are also unlikely to have major short-term demand impact. Correcting the cyclically adjusted budget for one-offs is thus likely to give a more accurate budgetary picture both from a discretionary and structural budget viewpoint.

\subsection{Problems with the previous treatment of one-offs}

8. Cyclically-adjusted fiscal balance data published in the OECD Economic Outlook, up to the $83^{\text {rd }}$ edition, were already adjusted for two sets of one-offs: third generation mobile telephone (UMTS) licence receipts around year 2000 (balance-improving one-offs) and selected cases of large capital payments such as debt assumptions that occurred in the 1990s (balance-deteriorating one-offs). The problem with this treatment was that the adjustment was partial and its scope limited. On the balance-improving side, UMTS licence receipts were adjusted for but other types of licence sales and, more generally, other revenueenhancing one-off operations (such as lump-sum payments to the government in exchange for the transfer of employees' pension rights or temporary increases in revenues resulting from tax amnesties) were not adjusted for (Table 1). Similarly, on the balance-deteriorating side, only three large capital payments that occurred in the 1990s in Germany, Japan and the Netherlands were adjusted for, even though the same type of transactions had affected fiscal balances in other countries. As an example, the 2004 debt assumptions for the Spanish railway company (RENFE) and the 2005 case of Belgium railway (SNCB) - about $0.7 \%$ and $2.4 \%$ of GDP respectively - were not adjusted for while adjustment was made for a similar operation in Japan in 1998. A second element of inconsistency existed with the previous treatment of one-offs: receipts from the sale of UMTS licences were excluded from cyclically adjusted balances but not from headline balances while the three capital payment items were excluded from both headline and cyclically adjusted balances. ${ }^{7}$

9. The previous methodology thus suffered from problems of consistency and coverage, both across OECD countries and over time. The following section begins with an evaluation of the difficulties of extending the disaggregated approach to include a more comprehensive set of one-off factors and this is followed by a closer examination of the treatment of one-offs in the national accounts to determine whether a more aggregate approach is possible. In either case, the objective is to create a revised set of indicators which continue to serve the dual purpose outlined above.

6. Tax amnesties do not necessarily change budget constraints for the household, merely changing the composition of their balance sheets with a drawdown of cash offset by cancellation of an outstanding tax liability. The fact that tax amnesties have relatively benign effects on real activities appears to be one of the reasons for its popularity in some countries. OECD (2005) discusses the issues related to tax amnesties, with specific reference to the recent Italian experience.

7. In these cases, headline fiscal balances presented in the OECD Economic Outlook database differ from those shown in the national accounts. 
Table 1. Current treatment of one-offs in the OECD Economic Outlook database

\begin{tabular}{|c|c|c|c|c|c|}
\hline \multirow[b]{2}{*}{$\begin{array}{l}\text { Impact on } \\
\text { balances }\end{array}$} & \multirow{2}{*}{\multicolumn{2}{|c|}{ Fiscal operations }} & \multicolumn{2}{|c|}{ Headline balances } & \multirow{2}{*}{$\begin{array}{l}\text { Cyclically-adjusted balances } \\
\text { OECD Economic Outlook } \\
\text { database up to 83rd edition }\end{array}$} \\
\hline & & & National Accounts & $\begin{array}{c}\text { OECD Economic } \\
\text { Outlook database up to } \\
\text { 83rd edition } \\
\end{array}$ & \\
\hline \multirow{3}{*}{$\begin{array}{l}\text { Balance- } \\
\text { improving }\end{array}$} & \multirow{2}{*}{$\begin{array}{l}\text { Licence } \\
\text { sales }\end{array}$} & $\begin{array}{l}\text { 3G mobile telephone licences } \\
\text { (UMTS) }\end{array}$ & Not adjusted & Not adjusted & Adjusted \\
\hline & & Other licence sales & Not adjusted & Not adjusted & Not adjusted \\
\hline & \multicolumn{2}{|c|}{$\begin{array}{l}\text { Other factors (e.g. tax amnesties, } \\
\text { pension transfers etc.) }\end{array}$} & Not adjusted & Not adjusted & Not adjusted \\
\hline \multirow{2}{*}{$\begin{array}{l}\text { Balance- } \\
\text { deteriorating }\end{array}$} & \multicolumn{2}{|c|}{$\begin{array}{l}\text { 1. Germany in } 1995 \text { (debt assumption) } \\
\text { 2. Netherlands in } 1995 \text { (capital injection) } \\
\text { 3. Japan in } 1998 \text { (debt assumptions) }\end{array}$} & Not adjusted & \multicolumn{2}{|c|}{ Adjusted } \\
\hline & \multicolumn{2}{|c|}{$\begin{array}{l}\text { Other factors (e.g. debt assumptions } \\
\text { other than listed above) }\end{array}$} & Not adjusted & Not adjusted & Not adjusted \\
\hline
\end{tabular}

\section{Difficulties of an approach based on an individual identification of one-offs}

10. One possible way forward would be to rely on a disaggregated approach in which one-offs are identified individually on a more systematic and comprehensive basis. Such estimates would then be used to compute a fiscal balance indicator net of one-offs. This is essentially the approach adopted by the European Commission: its regular assessment of fiscal positions of member states now relies on the "structural balance" defined as "cyclically adjusted balance excluding one-off and other temporary measures" (EC, 2006). ${ }^{8}$ The first requirement to implement this disaggregated approach is a definition of the criteria for fiscal operations to be recognised as one-offs (e.g. their nature and the length over which they have a direct impact on fiscal balances). Analysts would then have to identify one-offs for each country to compute and update relevant data series.

11. The practical implementation of this approach, however, may suffer from drawbacks that include the following:

- Criteria for identification. Despite a rather wide consensus for considering some operations as one-offs (e.g. exceptional revenues linked to the transfer of pension obligations), the list remains open and there is no clear-cut definition of what constitutes a one-off. Therefore, the identification of one-offs may ultimately depend on judgement calls by individual analysts, posing risks for cross-country consistency. In addition, a threshold below which one-offs would not be adjusted (e.g. as a percentage of GDP) would need to be set for, so as to make the procedure practically implementable. This involves a degree of arbitrariness, not least because many very small one-offs may add up to a considerable amount in some countries. Fiscal transactions of the same nature may also end up being treated inconsistently, depending on the level of the threshold.

- Information availability. The degree of availability of information concerning one-offs greatly varies by country, making it difficult to ensure cross-country, and possibly time, consistency. In some countries, identifying one-offs would require a substantial degree of data/information

8. Other attempts to identify one-offs based on a disaggregated approach include, for European countries, Besnard and Paul (2004a, 2004b), Girouard and Price (2004), Koen and van den Noord (2005) and, for Japan, Doihara, Masabuchi and Hasegawa (2006). The identification of one-offs made in these papers forms the basis of the examination of one-offs carried out in the next section. 
mining. This problem may be particularly acute for past one-offs, making it virtually impossible to derive a long historical series. ${ }^{9}$

- Complexity. The procedure would probably be too complex to be handled on a regular basis. For this approach to successfully identify one-offs in a manner that would be consistent both across countries and over time, substantial resources would be required.

\section{A closer examination of one-offs and capital transfers}

\subsection{One-offs are largely included in capital transfers}

12. To better understand the nature and impact of one-offs, an in-depth research from official and academic sources has been carried out for a small group of countries and a short period of time, thus keeping the procedure workable. Major one-offs have been identified from 1995 to 2007 for nine OECD countries (Belgium, France, Germany, Japan, Italy, the Netherlands, Portugal, United Kingdom and United States). ${ }^{10}$ The results of this exercise can be summarised as follows:

- The impacts of one-off operations on fiscal balances can be rather large - often exceeding $1 \%$ of GDP - and frequent in some countries (including Belgium, Italy, Japan and Portugal) as shown in Figure 1. One-off operations have been much less frequent and/or have had a smaller fiscal impact in some other countries (including France, Germany, the Netherlands, the United Kingdom and the United States).

- Most one-offs identified for the nine countries have been registered in, and affect fiscal balances through, net capital transfers: either receivables ("capital tax and transfers receipts") or payables ("capital transfers paid and other capital payments"). ${ }^{11}$ Table 2 shows that net capital transfers have often been affected by such one-off operations as "lump-sum payments to the government in exchange for the transfer of employees' pension rights", "tax amnesties", "licence sales" (all balance-improving) as well as "debt assumptions/cancellations" (balance-deteriorating).

9. Initial estimates of one-off factors may also need to be retroactively revised, as new information becomes available or, for EU countries, when decisions by Eurostat amend previous accounting treatments.

10. The selection of countries has been largely dictated by information availability, with due consideration for the variety of past one-off operations as well as for geographical diversity. The Appendix provides a detailed list of one-offs identified in this paper, with data and sources used to identify them. Though most large one-offs have probably been identified, some minor ones may not have been accounted for.

11. The OECD Analytical Data Base (ADB) used in this paper differs slightly from the national accounts in its categorical aggregation. On the payables side, the category "capital transfers paid and other capital payments" used in ADB includes "acquisitions less disposals of non-produced non-financial assets" and "changes in inventories and acquisitions less disposals of valuables" in addition to "capital transfers, payable" itself. On the receivables side, the category "capital tax and transfers receipts" is identical to the national account entry of "capital transfers, receivable". The term "net capital transfers" used throughout this paper is defined as "capital tax and transfers receipts" minus "capital transfers paid and other capital payments", as recorded in ADB. For details on the System of National Accounts (SNA), see Eurostat (2002) and United Nations (2001). 
- While net capital transfers are often highly volatile, once adjusted for identified one-offs they follow a rather smooth pattern (Figure 2). Their level, however, differs across countries and displays a trend for some of them. This point is further discussed in the next subsection.

- A very limited numbers of one-offs are not recorded as capital transfers. These one-offs typically take the form of temporary tax receipts resulting from shifts in the timing of tax payments - the cases of Japan and Italy detailed in the Appendix are revealing. The impact of these types of oneoffs on fiscal balances, however, tends to be smaller. ${ }^{12}$

Overall, these findings indicate that changes in net capital transfers can play a key role in identifying one-offs, as large changes in net capital transfers are often caused by one-offs.

Table 2. Examples of one-offs affecting fiscal balances through net capital transfers

\begin{tabular}{|c|c|c|c|}
\hline $\begin{array}{l}\text { Impact on } \\
\text { balances }\end{array}$ & Accounting classification & Types of transactions & Examples (countries and size per year) ${ }^{1}$ \\
\hline \multirow{6}{*}{$\begin{array}{l}\text { Balance- } \\
\text { improving }\end{array}$} & \multirow{5}{*}{$\begin{array}{l}\text { Increase in } \\
\text { "capital tax and } \\
\text { transfers receipts" }\end{array}$} & $\begin{array}{l}\text { Lump-sum payment to the government in } \\
\text { exchange for the transfer of employees' pension } \\
\text { rights }\end{array}$ & $\begin{array}{l}\text { Japan: } 2003 \text { to } 2007 \text { up to }+1.4 \% \\
\text { France: } 1997+0.5 \%, 2005+0.5 \% \\
\text { Belgium: } 2003 \text { to } 2005 \text { up to }+1.8 \% \\
\text { Portugal: } 1997+0.4 \%, 2003+0.9 \%, 2004+2.1 \%\end{array}$ \\
\hline & & Tax amnesties concerning undeclared assets & $\begin{array}{l}\text { Italy: } 1995+0.3 \%, 2002 \text { to } 2004 \text { up to }+1.4 \% \\
\text { Belgium: } 2004+0.2 \%\end{array}$ \\
\hline & & Court rulings in favour of the government & $\begin{array}{l}\text { Belgium: } 2005+0.1 \% \\
\text { Netherlands: } 1996 \text { to } 1997 \text { up to }+0.2 \%\end{array}$ \\
\hline & & $\begin{array}{l}\text { "Special" payment receipts from the Fiscal Loan } \\
\text { Fund Special Account }\end{array}$ & Japan: 2006 and 2007 up to $+1.8 \%$ \\
\hline & & Temporary tax increases (capital tax) & Italy: $1997+0.6 \%$ \\
\hline & $\begin{array}{l}\text { Decrease in "capital transfers paid } \\
\text { and other capital payments" }\end{array}$ & Sales of licences & $\begin{array}{l}14 \text { countries around } 2000 \text { up to } 2.5 \% \text { (UMTS) } \\
\text { Portugal: } 2002+0.2 \% \text { (Toll rights) }\end{array}$ \\
\hline \multirow{5}{*}{$\begin{array}{c}\text { Balance- } \\
\text { deteriorating }\end{array}$} & \multirow{5}{*}{$\begin{array}{l}\text { Increase in "capital transfers and } \\
\text { other capital payments" }\end{array}$} & Debt assumptions & $\begin{array}{l}\text { Japan: } 1998-5.3 \% \\
\text { Germany: } 1995-6.5 \% \\
\text { Belgium: } 2005-2.4 \% \\
\end{array}$ \\
\hline & & Debt cancellations & $\begin{array}{l}\text { Japan: } 2003-0.3 \% \\
\text { Italy: } 2006-0.9 \%\end{array}$ \\
\hline & & Deposit insurance related expenditures & Japan: 1998 to 2003 up to $-1.2 \%$ \\
\hline & & $\begin{array}{l}\text { Purchases of land related to highway } \\
\text { privatisation }\end{array}$ & Japan: $2005-1.8 \%$ \\
\hline & & $\begin{array}{l}\text { Exceptional capital injection to the social rental } \\
\text { company }\end{array}$ & Netherlands: $1995-4.8 \%$ \\
\hline
\end{tabular}

1. Figures are expressed as a percentage of potential GDP. A positive sign indicates that the one-off operation contributes to improve the fiscal balance.

12. There are a few exceptions (notably for Portugal and the United Kingdom), which will be discussed later. 
Figure 1. Level and composition of one-offs affecting fiscal balances for selected OECD countries Per cent of potential GDP (different scales)
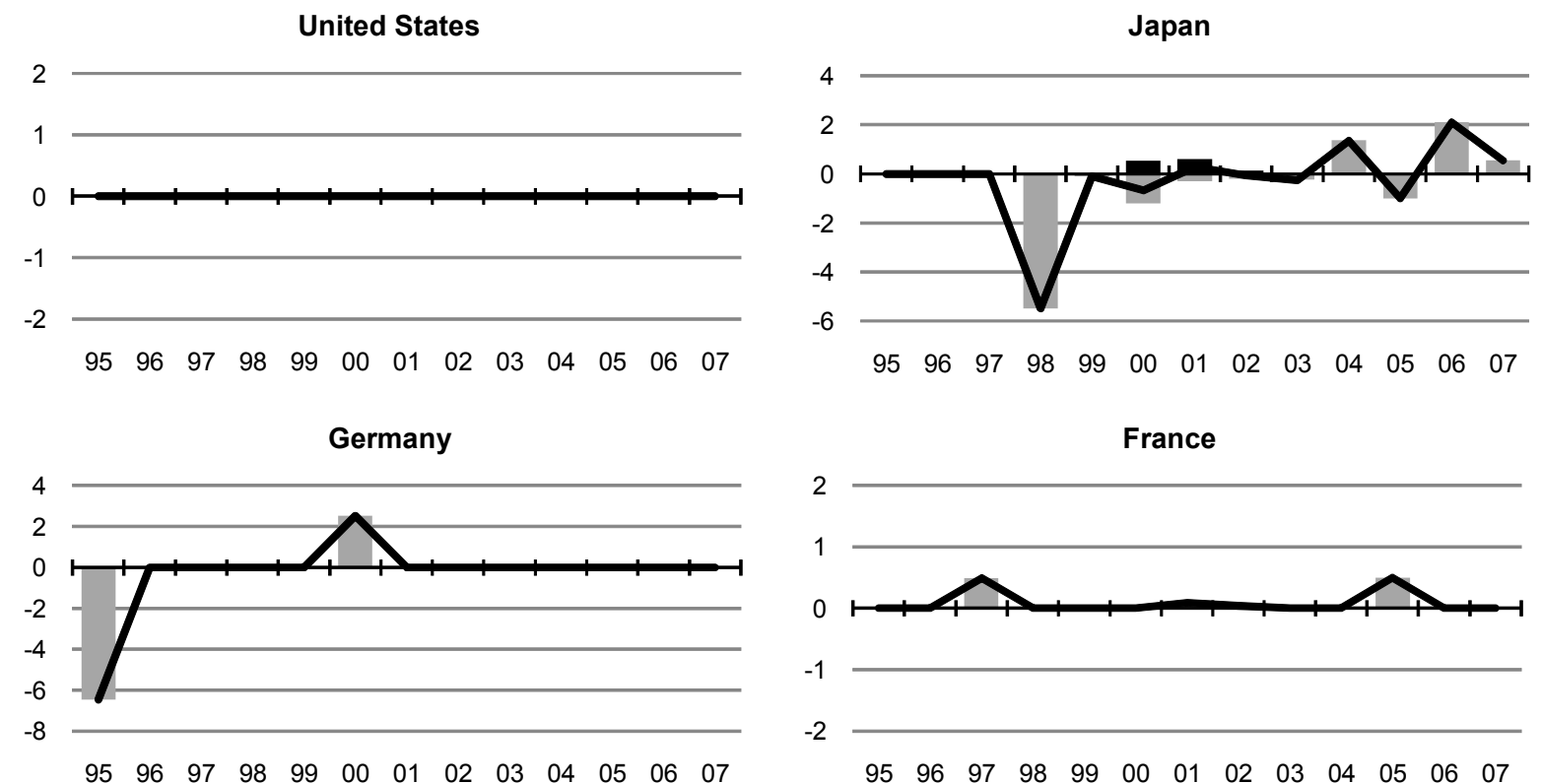

Italy

$\begin{array}{lllllllllllll}95 & 96 & 97 & 98 & 99 & 00 & 01 & 02 & 03 & 04 & 05 & 06 & 07\end{array}$

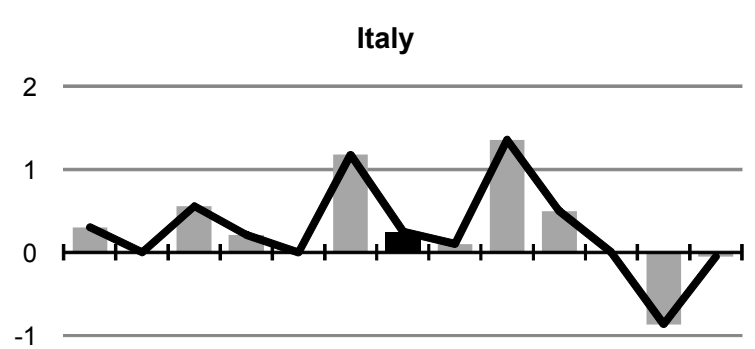

$\begin{array}{lllllllllllll}95 & 96 & 97 & 98 & 99 & 00 & 01 & 02 & 03 & 04 & 05 & 06 & 07\end{array}$

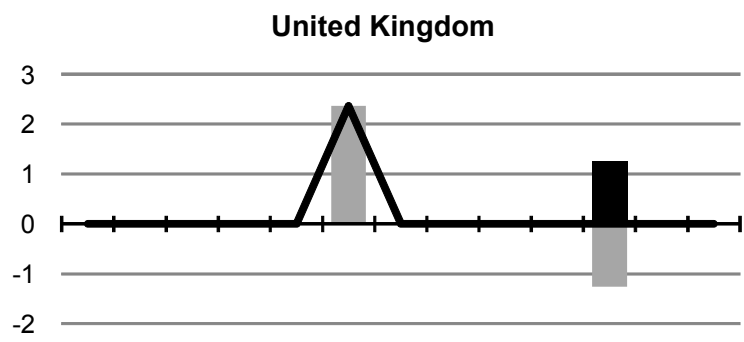

Belgium

$\begin{array}{lllllllllllll}95 & 96 & 97 & 98 & 99 & 00 & 01 & 02 & 03 & 04 & 05 & 06 & 07\end{array}$
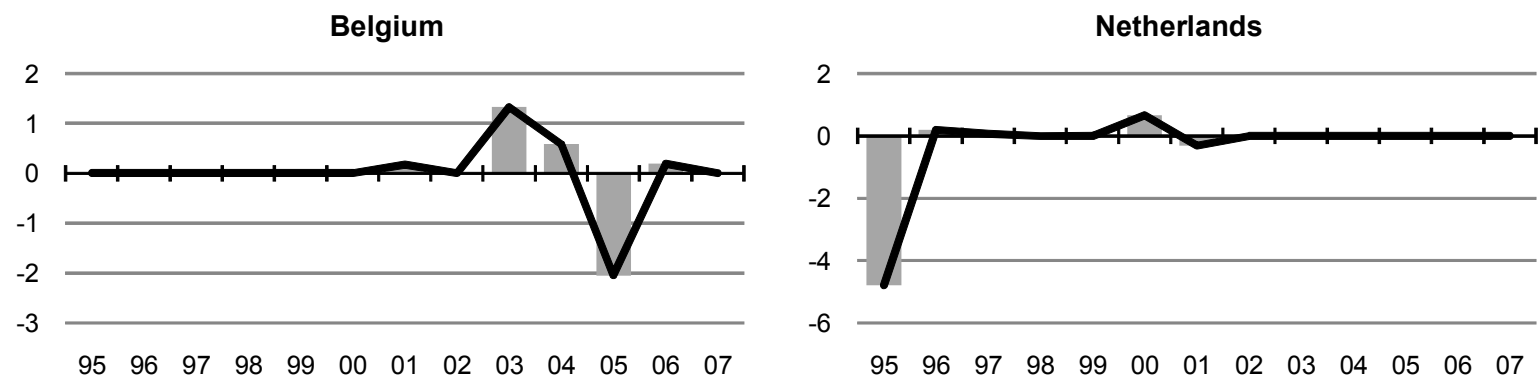

Portugal
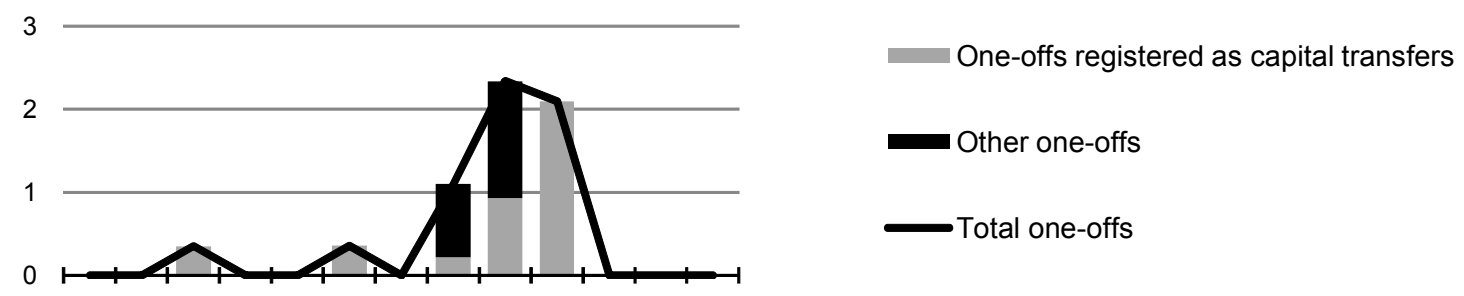

$\begin{array}{lllllllllllll}95 & 96 & 97 & 98 & 99 & 00 & 01 & 02 & 03 & 04 & 05 & 06 & 07\end{array}$

Source: Box 2 in the Appendix for the one-offs; OECD Economic Outlook 83 database for potential output data. 
Figure 2. Net capital transfers and one-offs for selected OECD countries

Per cent of potential GDP
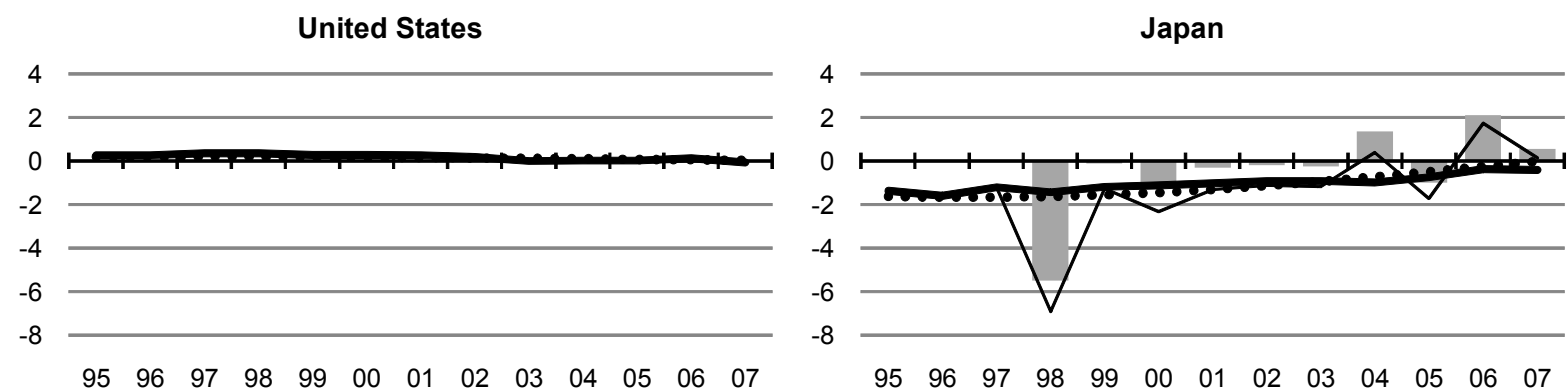

Germany
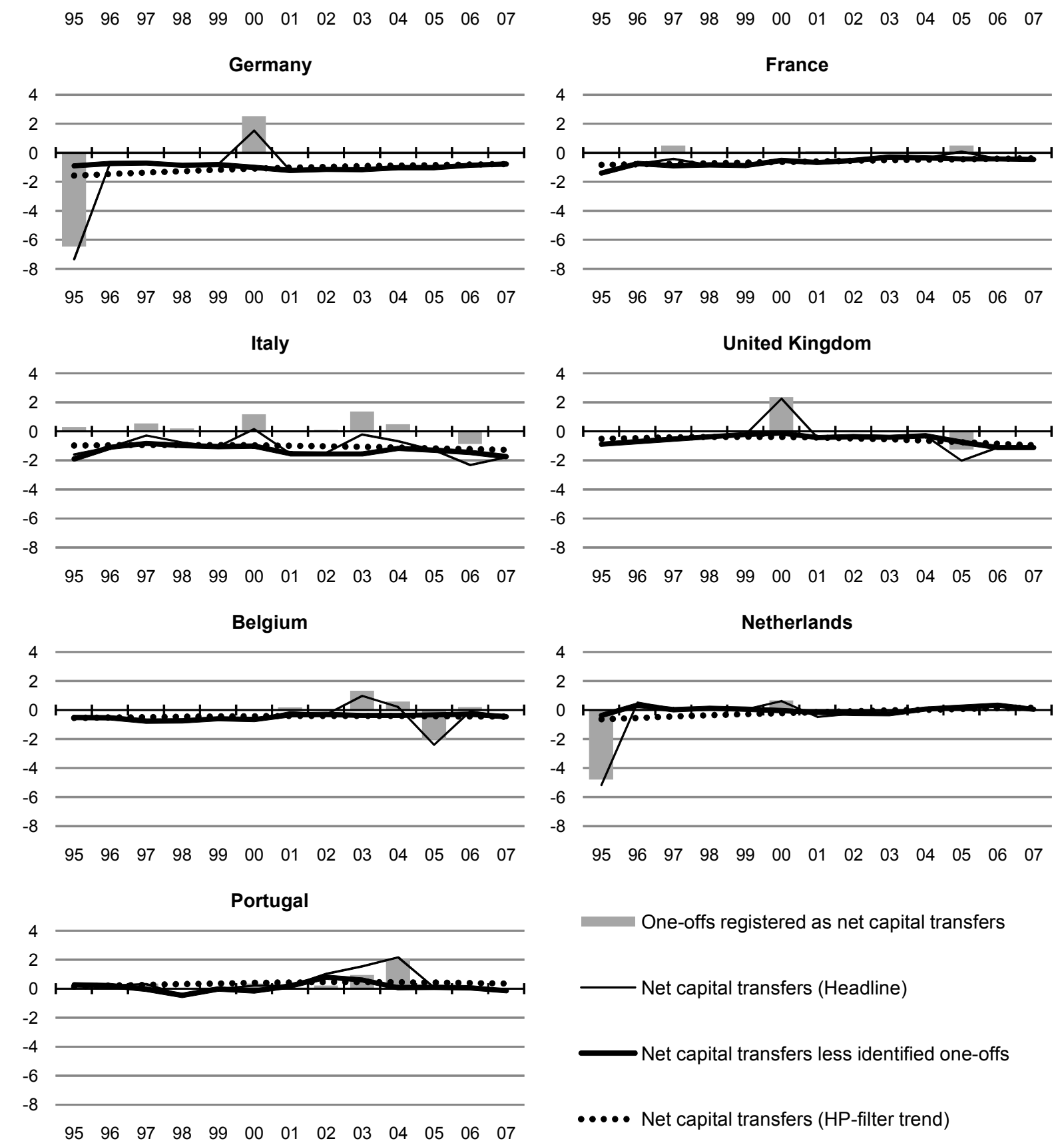

Source: Box 2 in the Appendix for the one-offs; OECD Economic Outlook 83 database for potential output and capital transfers. 
ECO/WKP(2008)50

\subsection{Cross-country differences in levels and trends of net capital transfers}

13. Net capital transfers include several recurrent fiscal transactions, over and above one-offs. The nature of these recurrent transactions (Table 3) can explain why the size of net capital transfers differs significantly across countries and why, for some countries, net capital transfers exhibit some trend (Figure 3). Available information, sketchy as it is, reveals that the following factors are likely to be important:

- On the receivables side, capital taxes (including gift or inheritance taxes) generally account for a large part of total capital transfers received. ${ }^{13}$ This category of receipts, however, does not lead to large cross-country differences: capital taxes amount to at most around $0.5 \%$ of GDP in the absence of one-offs. For some countries, the receivables include investment grants made by the rest of the world and this creates large differences in levels across countries. For instance, the receivables are quite large for Greece, Ireland, Portugal and Spain, reflecting receipts of structural funds from the institutions of the European Union.

- On the payables side, cross-country differences are more striking. Capital injections to cover repeated losses of public companies and investment grants paid out to third parties (possibly including public corporations) to acquire fixed assets seem to account for the overwhelming portion of the total payables. ${ }^{14}$ And differences in the role of the government, including its relationship with public corporations, could be an important factor explaining differences in the level of capital transfers across countries. In addition, countries whose governments are actively involved in land-related transactions (in particular Japan and the Netherlands) show corresponding entries on the payables side. ${ }^{15}$ For some countries, debt forgiveness granted to developing countries has also had some, though limited, impact.

- In addition to the differences in size, net capital transfers of some countries show mild trends, mostly in a balance-improving direction coming from the payable side. An explanatory factor may be the changing role of the government, and the public sector more generally, against the backdrop of increased fiscal discipline, reduced government ownership of companies as well as a more hands-off approach to those remaining publicly owned. As an indication, cash-based budget data for the central government in Spain show that capital transfer payments from the central government to public enterprises was reduced from about 1\% of nominal GDP in the mid 1980s

13. Taxes on capital gains are not included in capital taxes. According to the SNA 1993, taxes paid on capital gains are classified as current taxes on income.

14. Available data for 11 OECD countries suggest that investment grants account for the lion's share on the payable side - e.g. $89 \%$ of the total "capital transfers paid and other capital payments" in Belgium, $54 \%$ in Finland, $69 \%$ in Germany, and $94 \%$ in the United Kingdom (figures are medians of the available historical national account data from 1980 onward). National accounts data do not provide information as to the recipients of these investment grants, however.

15. As for licences, land is treated as a non-produced non-financial asset. Both sales and purchases of land are thus recorded in "acquisition less disposals of non-produced non-financial assets", which comprises "capital transfers paid and other capital payments" in the OECD's analytical database. In the absence of one-offs (such as licence sales), this category tends to be rather small, with the notable exceptions of Japan and the Netherlands. For the Netherlands, this category tends to improve fiscal balances, mainly because of the sales of land by public (municipal) development corporations to investors in dwellings and nonresidential buildings. As for Japan, this category tends to deteriorate the fiscal balance significantly, reflecting the cost of land acquisitions for public works. 
to about $0.1 \%$ in recent years. Besides, better tax administration may also have played a role in those countries where uncollected tax liabilities are recorded as negative net capital transfers. ${ }^{16}$

Table 3. Net capital transfers: major components

\begin{tabular}{|c|c|c|c|c|}
\hline $\begin{array}{c}\text { OECD Analytical } \\
\text { Database }\end{array}$ & \multicolumn{2}{|c|}{ National account definitions } & General examples & One-off examples \\
\hline \multirow{3}{*}{$\begin{array}{l}\text { Capital tax and } \\
\text { transfers receipts }\end{array}$} & \multirow{3}{*}{$\begin{array}{l}\text { Capital } \\
\text { transfers, } \\
\text { receivable }\end{array}$} & Capital tax & $\begin{array}{l}\text { 1) Taxes on capital transfers: inheritance taxes, death duties and } \\
\text { taxes on gifts inter vivos etc. } \\
\text { 2) Capital levies: occasional and exceptional levies on assets or net } \\
\text { worth (does not include capital gains taxes). }\end{array}$ & $\begin{array}{l}\text { Tax amnesties on } \\
\text { undeclared assets }\end{array}$ \\
\hline & & Investment grants & Investment grants received from the institutions of the EU. & \\
\hline & & Others & $\begin{array}{l}\text { Any other receipts. } \\
\text { For some countries, "taxes assessed but unlikely to be collected" } \\
\text { are registered here with negative signs. }\end{array}$ & Pension transfers \\
\hline \multirow{4}{*}{$\begin{array}{l}\text { Capital transfers paid } \\
\text { and other capital } \\
\text { payments }\end{array}$} & \multirow{2}{*}{$\begin{array}{l}\text { Capital } \\
\text { transfers, } \\
\text { payable }\end{array}$} & Investment grants & $\begin{array}{l}\text { Investment grants made to public corporations or public } \\
\text { infrastructure projects. }\end{array}$ & \\
\hline & & Others & $\begin{array}{l}\text { Any other payments, including capital injections to cover repeated } \\
\text { losses of public corporations. }\end{array}$ & $\begin{array}{l}\text { Debt assumptions / } \\
\text { cancellations }\end{array}$ \\
\hline & \multicolumn{2}{|c|}{$\begin{array}{l}\text { Acquisitions less disposals of non- } \\
\text { produced non-financial assets }\end{array}$} & $\begin{array}{l}\text { Non-produced non-financial assets include tangible assets such as } \\
\text { land, as well as intangible assets such as goodwill and licences. }\end{array}$ & Licence sales \\
\hline & \multicolumn{2}{|c|}{$\begin{array}{l}\text { Changes in inventories and acquisitions } \\
\text { less disposals of valuables }\end{array}$} & $\begin{array}{l}\text { Valuables include precious stones and metals (not used for } \\
\text { production). }\end{array}$ & \\
\hline $\begin{array}{c}= \\
\text { Net capital transfers }\end{array}$ & & & & \\
\hline
\end{tabular}

\section{Building an "underlying" fiscal balance indicator}

14. An appropriate assessment of fiscal positions would require the production of a fiscal balance indicator which: $i$ ) effectively eliminates the impact of one-offs (in addition to the adjustment for cyclical conditions), and ii) maintains comparability both across countries and over time as to how one-off operations are treated. Additionally, the procedure for calculating the new fiscal indicator should not be overly complex, since the indicator is expected to be used regularly and updated in the semi-annual projection exercises by the OECD.

15. Deriving a proxy for the one-offs from national account data which are widely available and consistent both over time and across countries, is an attractive option. The previous section has shown that abrupt changes in net capital transfers often indicate one-offs, while the level and trend in net capital transfers are country-specific. In the absence of one-offs, net capital transfers can be assumed to show a smooth development over time. This suggests that, for each country, there would be a level or a trend of net capital transfers that could be considered as "normal" and deviations of net capital transfers from this country-specific benchmark could provide a sensible proxy for one-offs.

16. The National accounts must allow for the possibility that a certain portion of assessed tax liabilities ends up uncollected. Some OECD countries directly adjust the corresponding tax receipt series. Others record negative capital transfer transactions corresponding to the amounts of tax revenues that are "assessed but unlikely to be collected". Data for France, Denmark, Spain and Slovak Republic show that this category has declined more or less steadily since the end of the 1990s, which has contributed to the positive trend in overall net capital transfers. While cyclical influences cannot be ruled out, there may be more structural factors (such as more efficient tax enforcement). 
Figure 3. Level and trend in capital transfers

Per cent of potential GDP (different scales)

United States

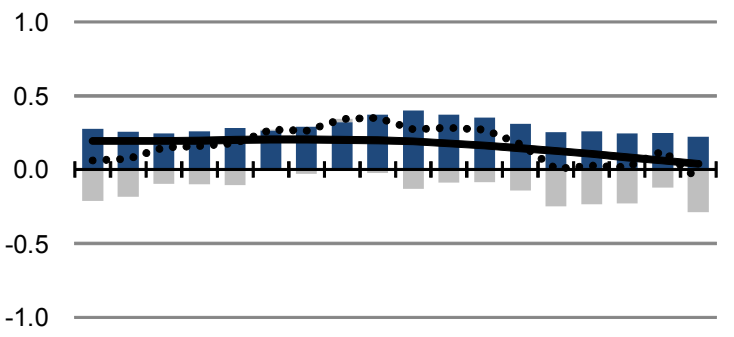

909192939495969798990001020304050607

Germany

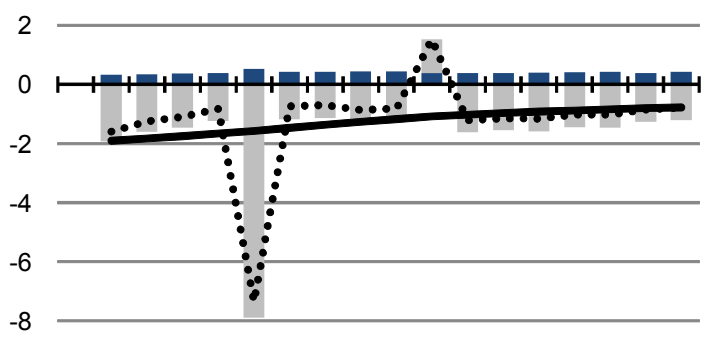

909192939495969798990001020304050607

Italy

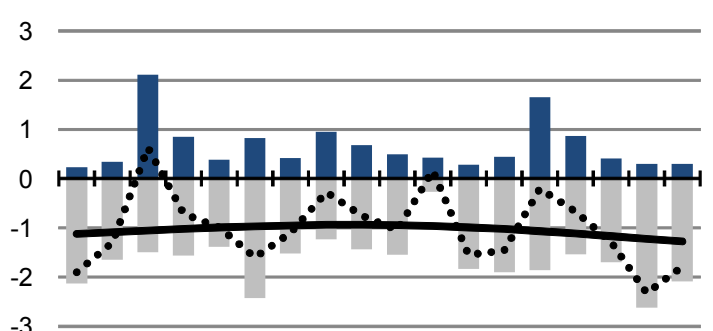

909192939495969798990001020304050607

\section{Canada}

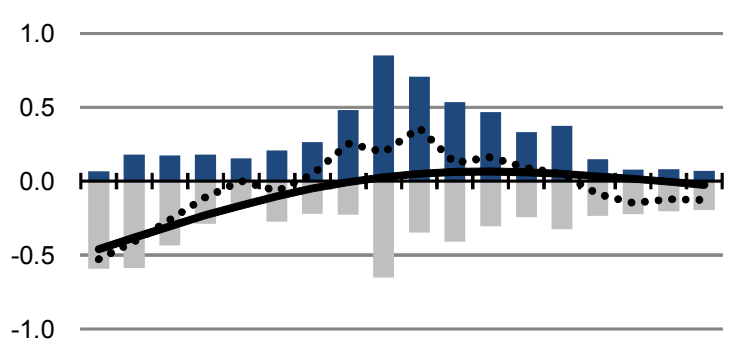

909192939495969798990001020304050607
Japan

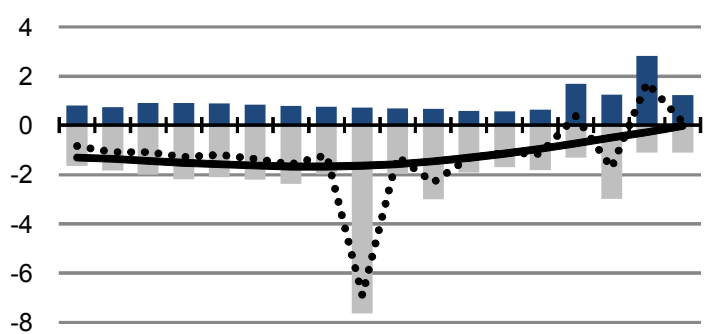

909192939495969798990001020304050607

France

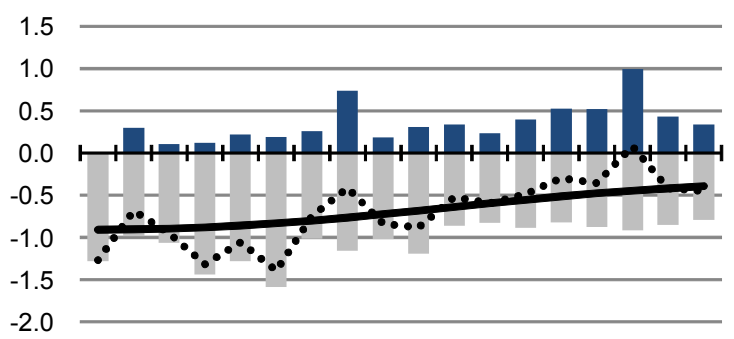

909192939495969798990001020304050607

\section{United Kingdom}

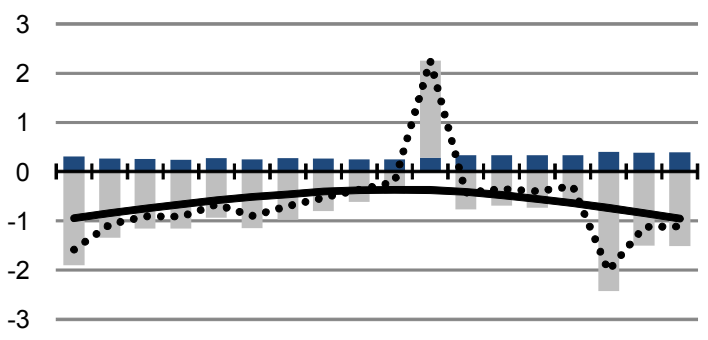

909192939495969798990001020304050607

Capital transfers payable

Capital transfers receivable

..... Net capital transfers

Net capital transfers: HP-filtered trend 
Figure 3. Level and trend in capital transfers (cont.)

Per cent of potential GDP (different scales)

\section{Australia}

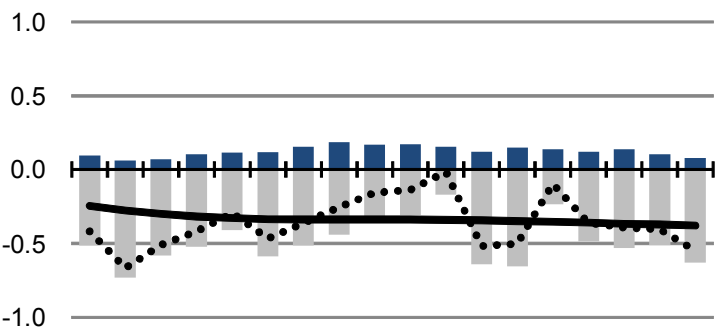

909192939495969798990001020304050607

Belgium

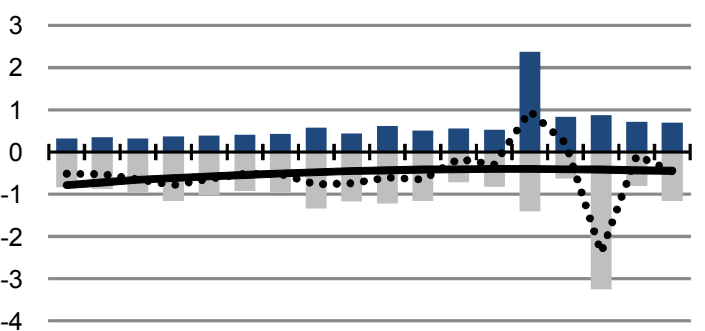

909192939495969798990001020304050607

Denmark

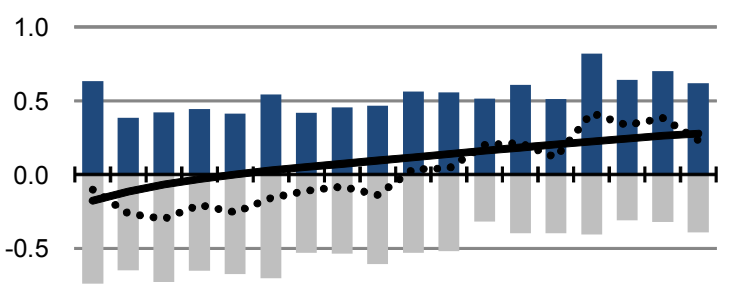

$-1.0$

909192939495969798990001020304050607

\section{Greece}

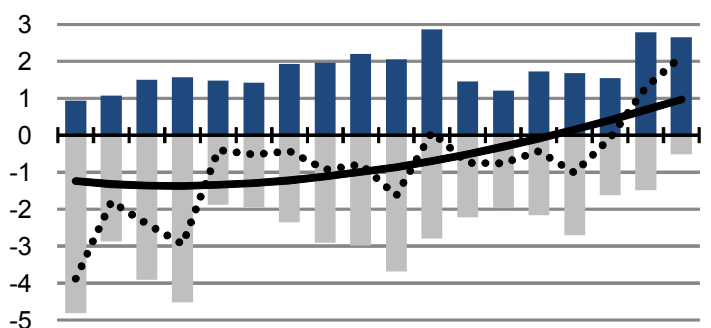

909192939495969798990001020304050607
Austria

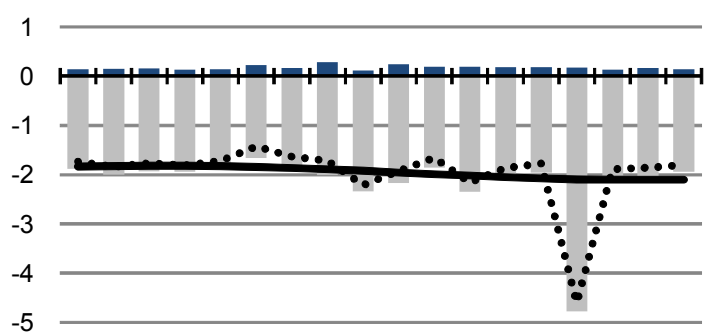

909192939495969798990001020304050607

Czech Republic

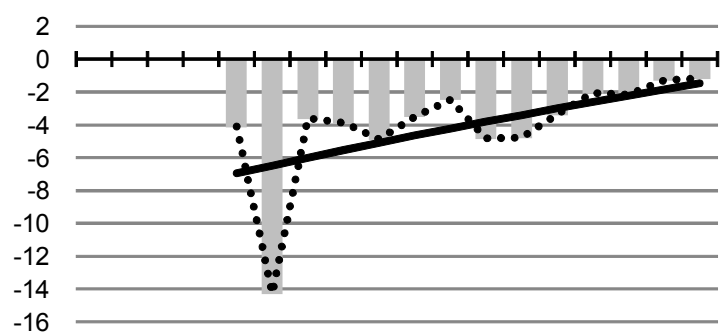

909192939495969798990001020304050607

Finland

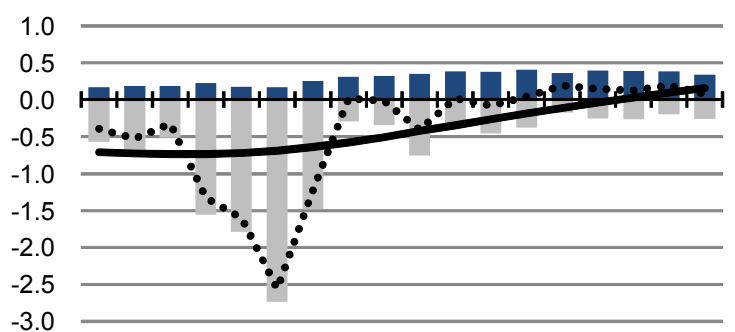

909192939495969798990001020304050607

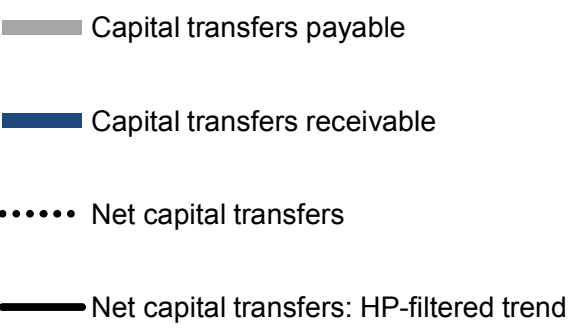

Source: OECD Economic Outlook 83 database and OECD calculations. 
Figure 3. Level and trend in capital transfers (cont.)

Per cent of potential GDP (different scales)

Hungary

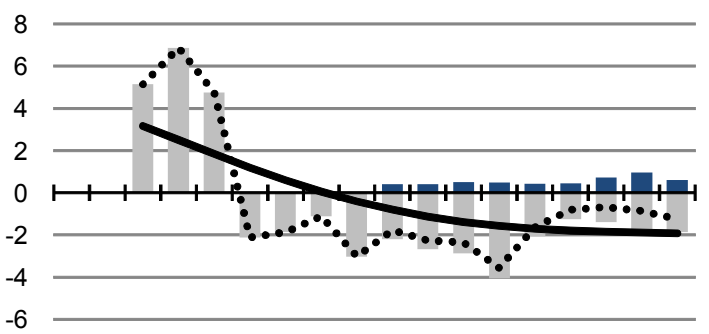

909192939495969798990001020304050607

Ireland

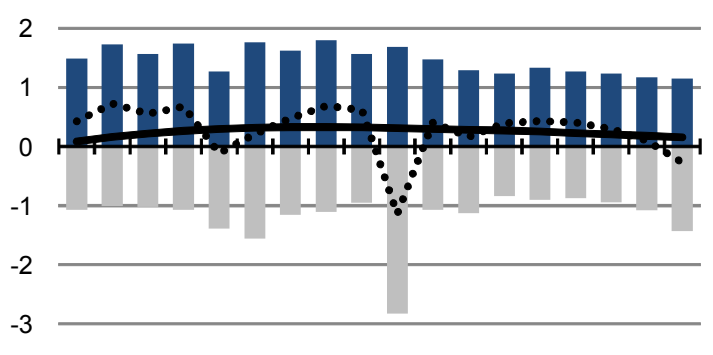

909192939495969798990001020304050607

\section{Luxembourg}

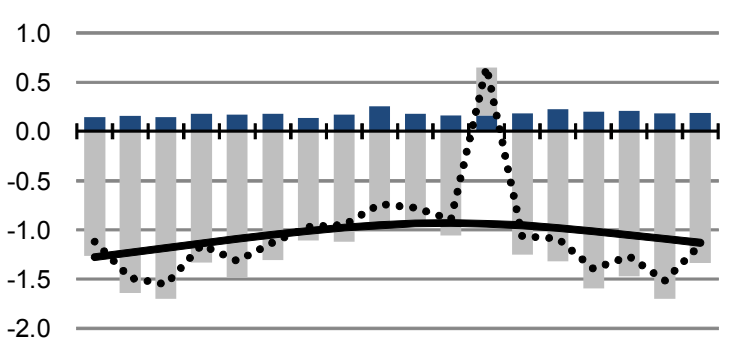

909192939495969798990001020304050607

New Zealand

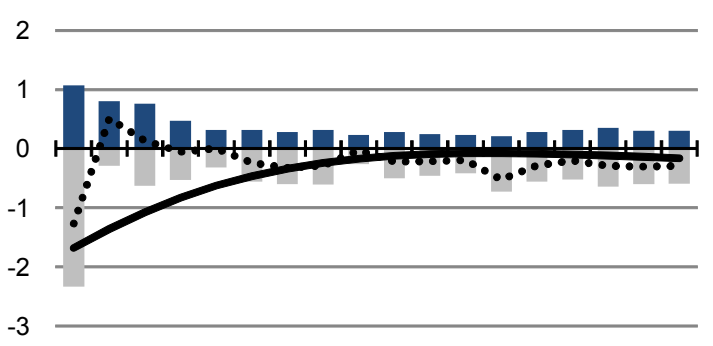

909192939495969798990001020304050607
Iceland

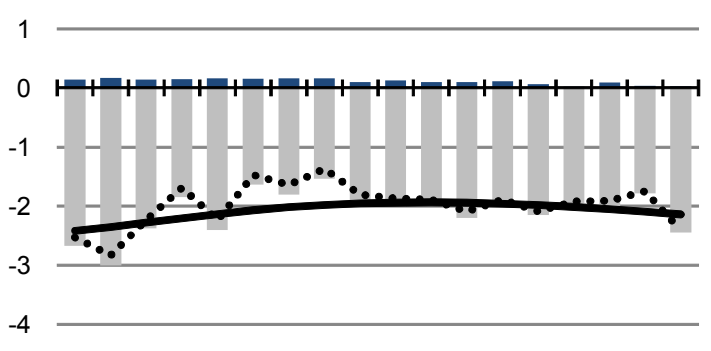

909192939495969798990001020304050607

Korea

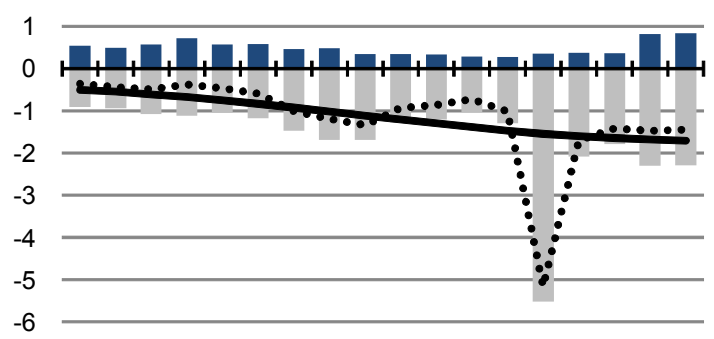

909192939495969798990001020304050607

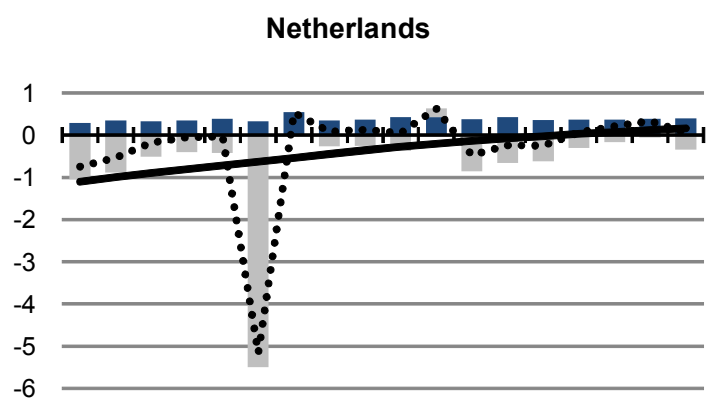

909192939495969798990001020304050607

Capital transfers payable

Capital transfers receivable

..... Net capital transfers

Net capital transfers: HP-filtered trend

Source: OECD Economic Outlook 83 database and OECD calculations. 
Figure 3. Level and trend in capital transfers (cont.)

Per cent of potential GDP (different scales)

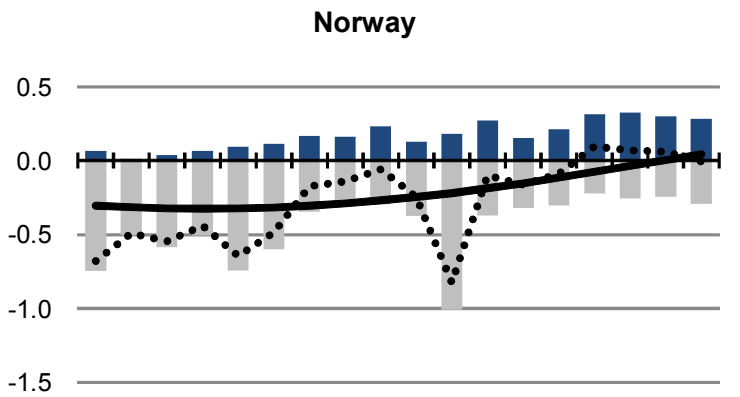

909192939495969798990001020304050607

Portugal

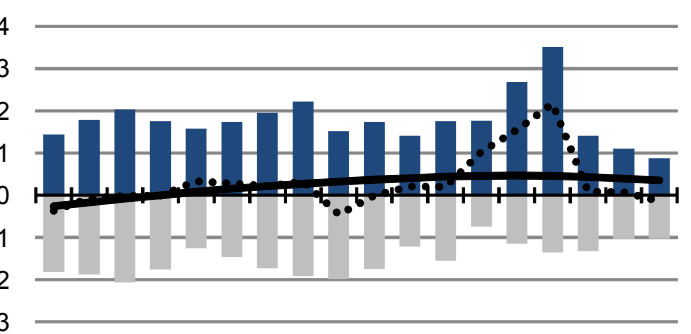

909192939495969798990001020304050607

Spain

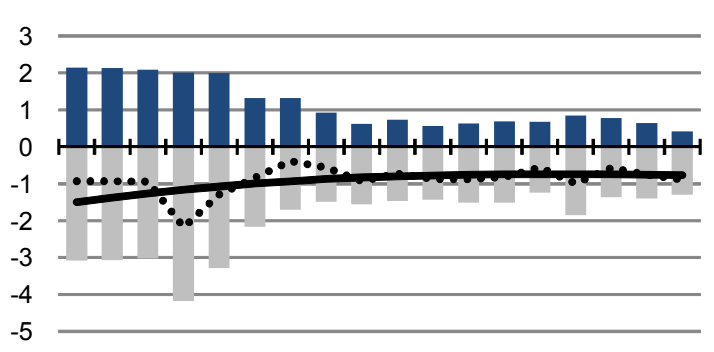

909192939495969798990001020304050607
Poland

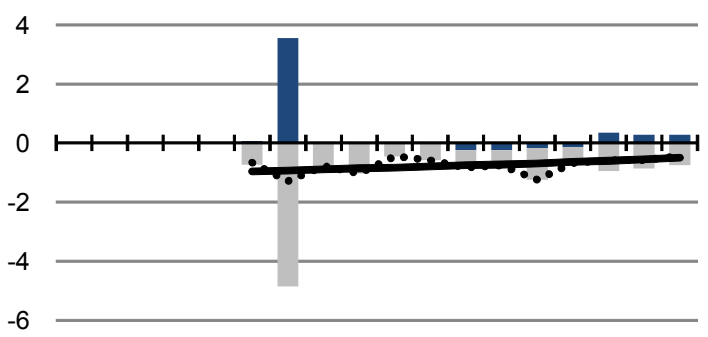

909192939495969798990001020304050607

Slovak Republic

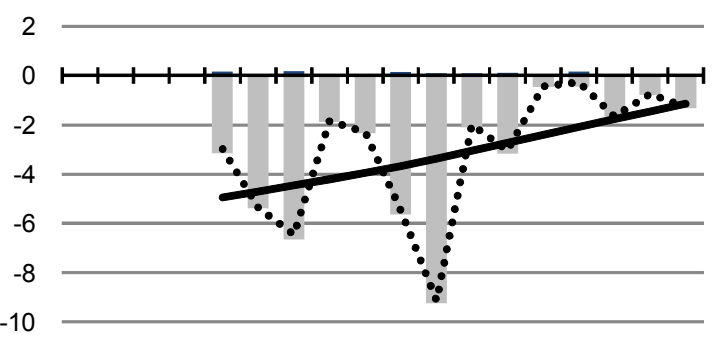

909192939495969798990001020304050607

Sweden

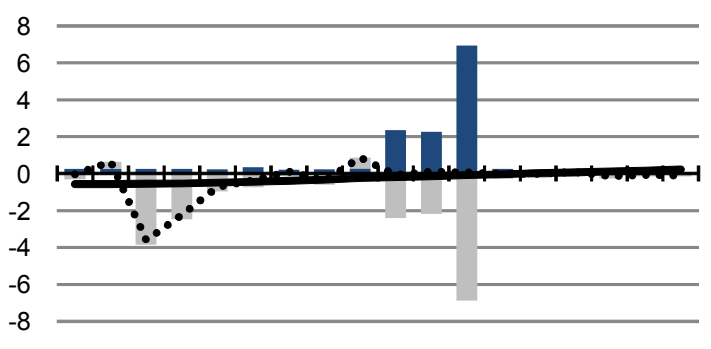

909192939495969798990001020304050607
Switzerland

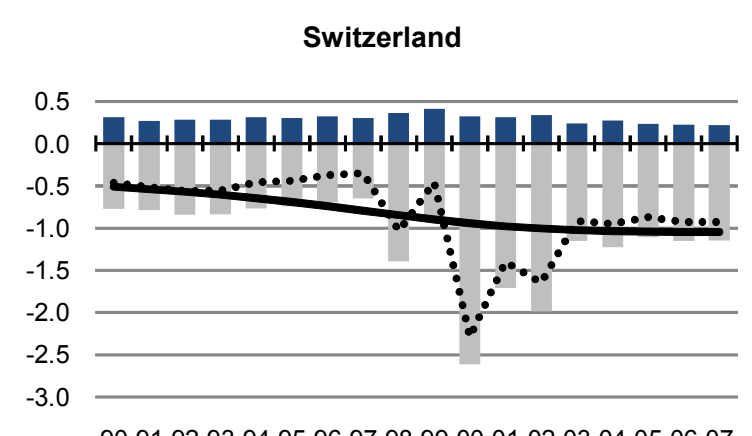

909192939495969798990001020304050607

Source: OECD Economic Outlook 83 database and OECD calculations. 
16. This process would seem to be consistent with the dual purpose of assessing fiscal sustainability and measuring discretionary fiscal stance. The indicator would take into consideration the "normal" level of net capital transfers when analysing fiscal balances from sustainability point of view. At the same time, the nature of these capital transfer transactions implies that short-term demand weight of large and abrupt changes of net capital transfers is most likely small. In that case, focus on the "normal" level of net capital transfers would also be expected to lead to a better measure of fiscal stance.

\subsection{Filtering net capital transfers to identify and remove one-offs}

17. The country-specific "normal" level of net capital transfers can be derived using various statistical methods. Several have been experimented, including simple averages, fixed medians, rolling medians and HP filters. It would be inappropriate to use simple averages, because they can be significantly affected by the existence of one-offs. The use of medians may be preferable, as they are less affected by outliers, but some form of "rolling" would be required in order to account for a trend in net capital transfers, if any. A trade-off emerges in determining the length of the period over which the rolling median would be calculated. Taking a sufficiently long period of time would ensure that results are not overly affected by the incidence of one-offs. However, taking too long a period would make it difficult to detect changes in trend, while reducing the availability of data for the early years. ${ }^{17}$

18. Smoothing net capital transfers by relying on a Hodrick-Prescott (HP) filter has clear advantages. The HP filter allows deriving long-term trends that are not overly sensitive to short-term fluctuations or outliers, without losing data availability in terms of the number of years. As to the smoothness of the filtering, some degree of rigidity is important to prevent one-offs from having unduly large impacts on trend derivation. Thus, the smoothing parameter for the HP filter $(\lambda)$ has been set at 400 , instead of the commonly-used value for annual series of 100 . This rather rigid filter also helps mitigating the end-ofsample problem inherent in the use of HP filters. In addition, HP filtering has been applied to long time series, starting in 1980 (when available) and ending in 2009 (based on two-year-ahead projections published in the OECD Economic Outlook, No. 83). Figure 3 shows actual and filtered net capital transfers.

\subsection{Implementing an "underlying" fiscal balance indicator}

19. Fiscal balances adjusted for cyclical fluctuations and one-offs - named "underlying" fiscal balances - can be constructed from the headline balances as follows:

Headline fiscal balance (as shown in the national account data)

- Cyclical factors (estimated using the methodology described in Girouard and André, 2005)

- One-offs (proxied as deviations of net capital transfers from a "normal", HP-filter, level)

$=$ Underlying fiscal balance

Figure 4 shows how the resulting underlying fiscal balance indicator compares with headline and cyclically-adjusted fiscal balances.

17. For some countries, national accounts data for net capital transfers are only available from the $1990 \mathrm{~s}$. 
Figure 4. Headline, cyclically-adjusted and underlying fiscal balances

Per cent of potential GDP (different scales)

United States

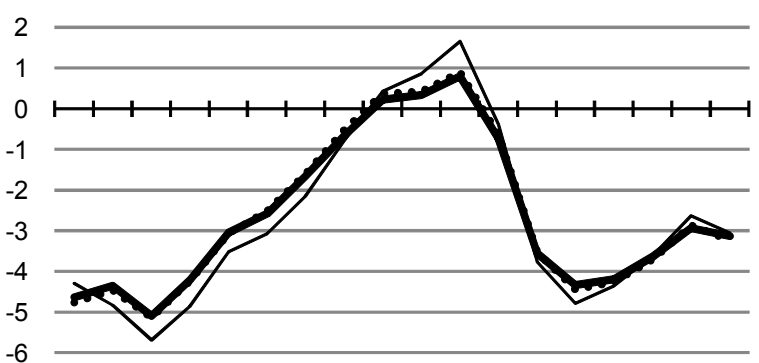

909192939495969798990001020304050607

Germany

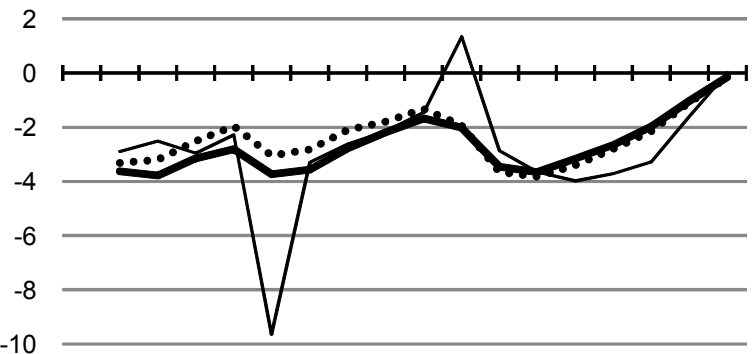

909192939495969798990001020304050607

Italy

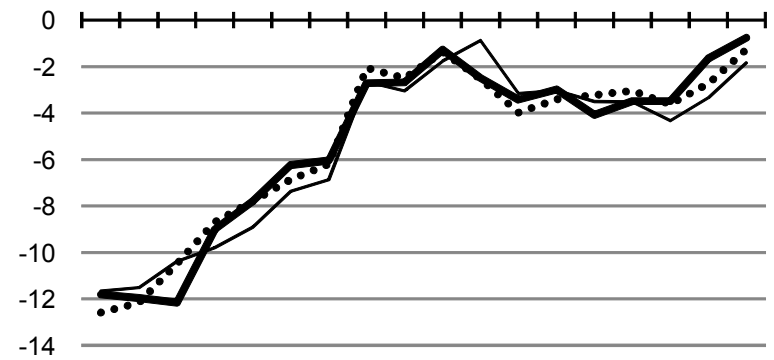

909192939495969798990001020304050607

Canada

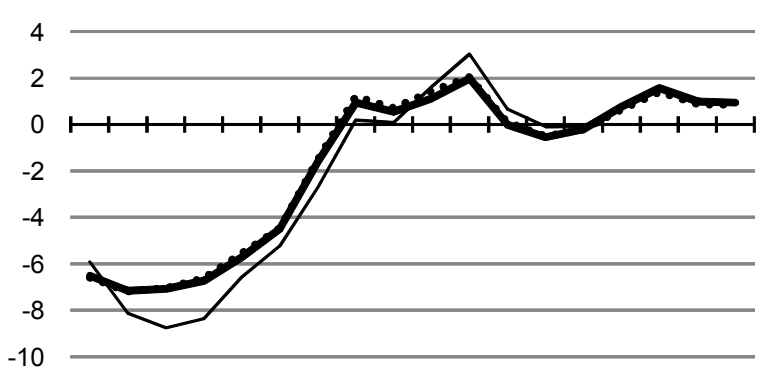

909192939495969798990001020304050607
Japan

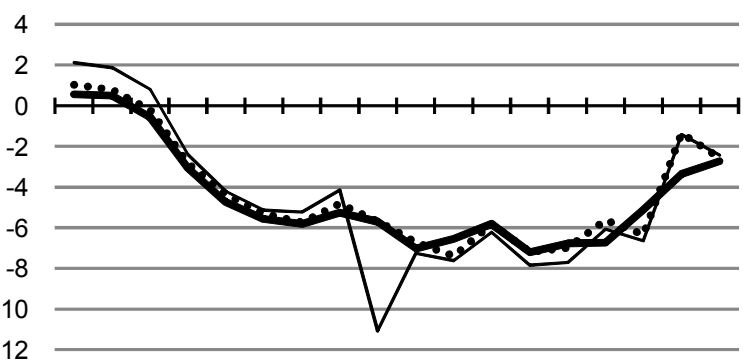

909192939495969798990001020304050607

France

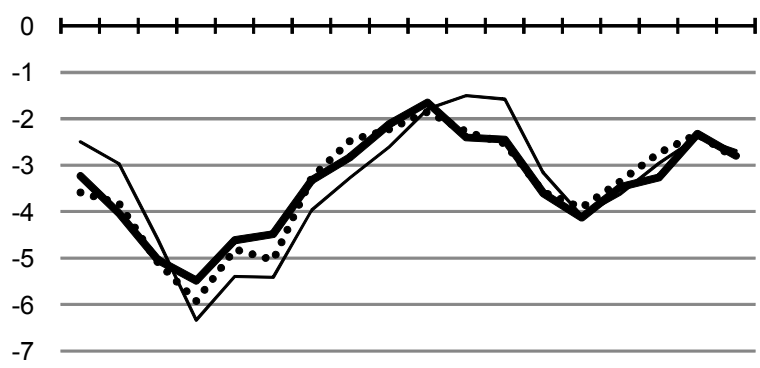

909192939495969798990001020304050607

United Kingdom

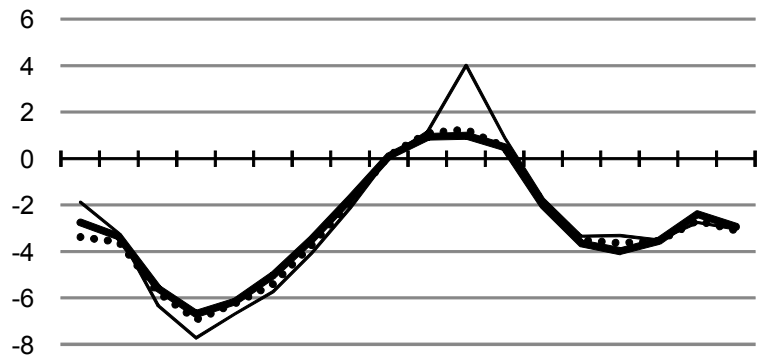

909192939495969798990001020304050607
- Headline balance (1)

Cyclically-adjusted balance (1)

Underlying balance

1. Ad-hoc adjustments on one-offs made in the OECD Economic Outlook database up to the 83rd edition have been repealed. Source: OECD Economic Outlook 83 database. 
Figure 4. Headline, cyclically-adjusted and underlying fiscal balances (cont.)

Per cent of potential GDP (different scales)

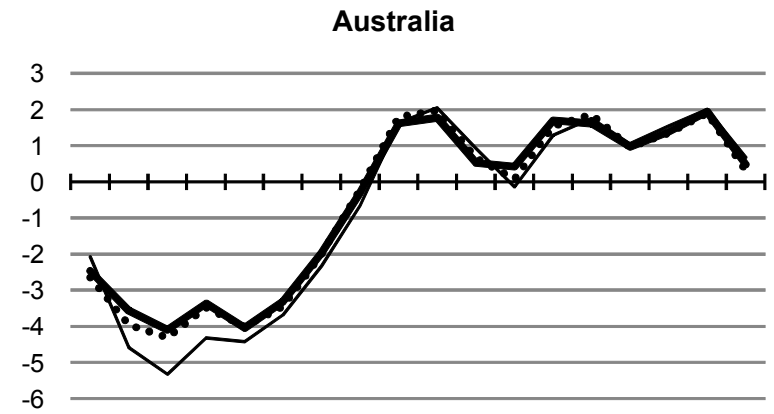

909192939495969798990001020304050607

Belgium

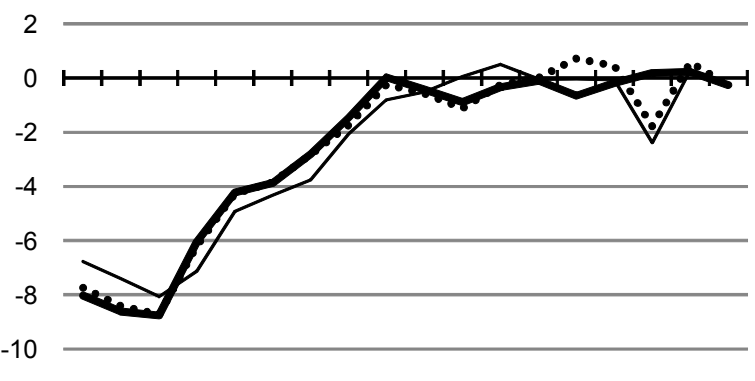

909192939495969798990001020304050607

Denmark

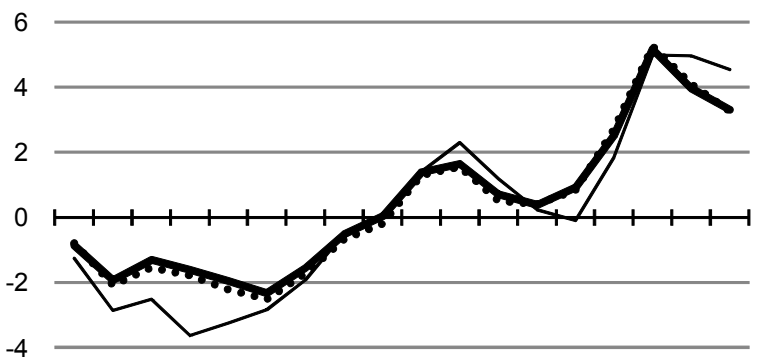

909192939495969798990001020304050607

\section{Greece}

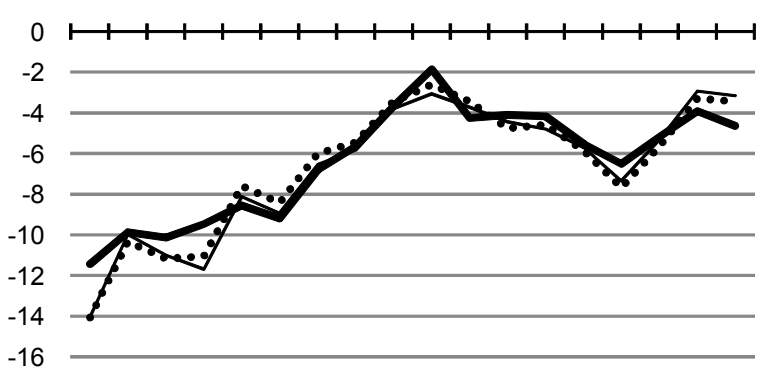

909192939495969798990001020304050607

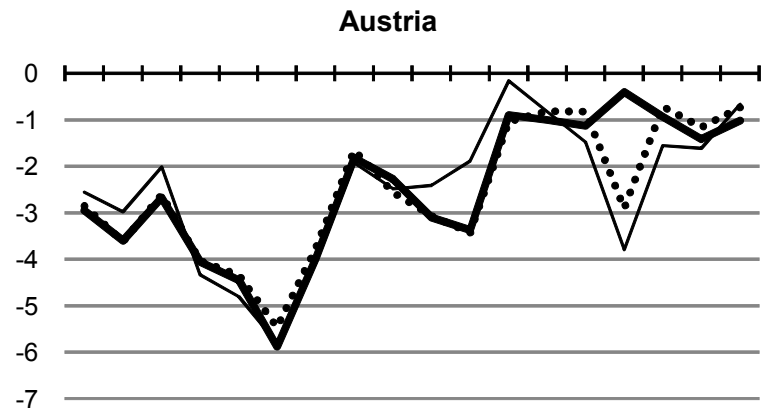

909192939495969798990001020304050607

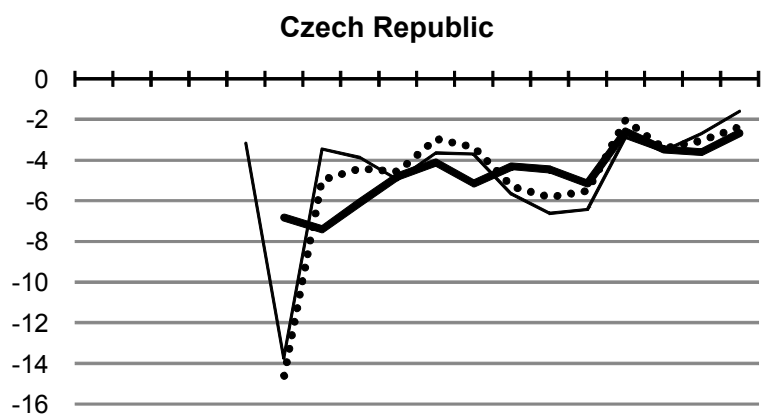

909192939495969798990001020304050607

Finland

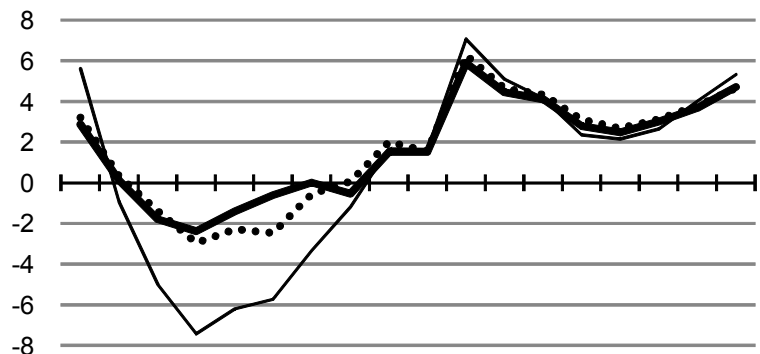

909192939495969798990001020304050607
- Headline balance (1)

Cyclically-adjusted balance (1)

Underlying balance

1. Ad-hoc adjustments on one-offs made in the OECD Economic Outlook database up to the 83rd edition have been repealed. Source: OECD Economic Outlook 83 database. 
Figure 4. Headline, cyclically-adjusted and underlying fiscal balances (cont.)

Per cent of potential GDP (different scales)

Hungary

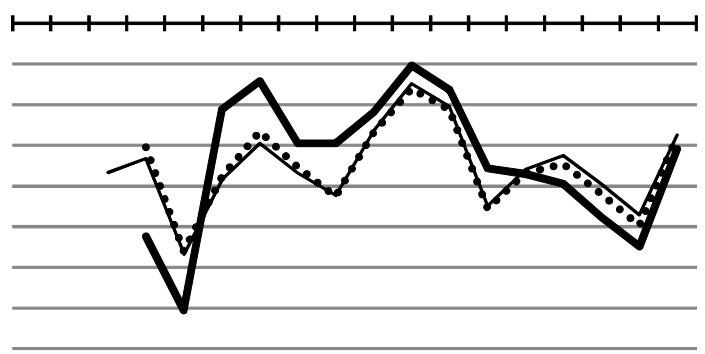

909192939495969798990001020304050607

Ireland

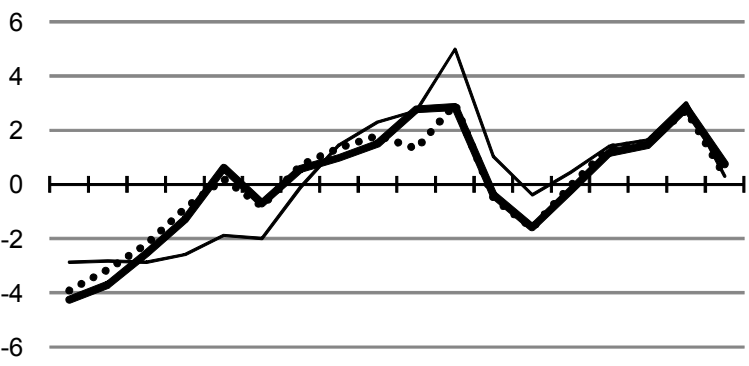

909192939495969798990001020304050607

Luxembourg

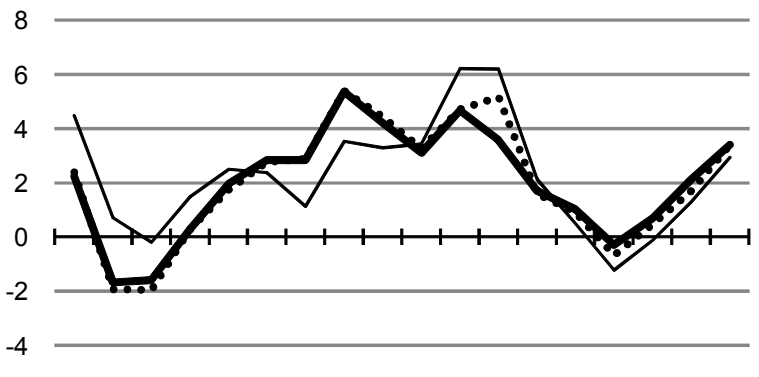

909192939495969798990001020304050607

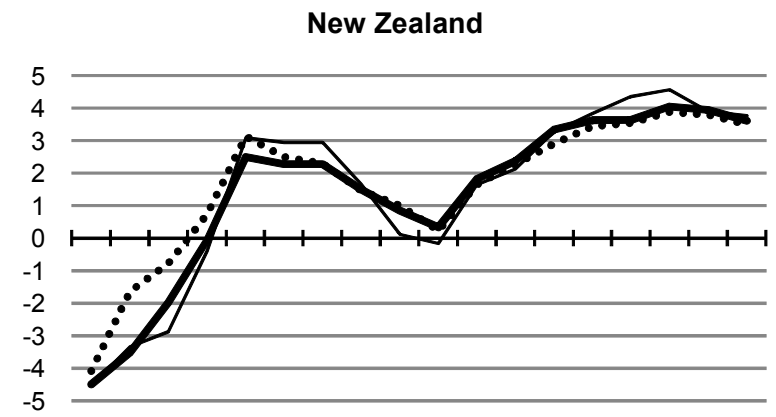

909192939495969798990001020304050607

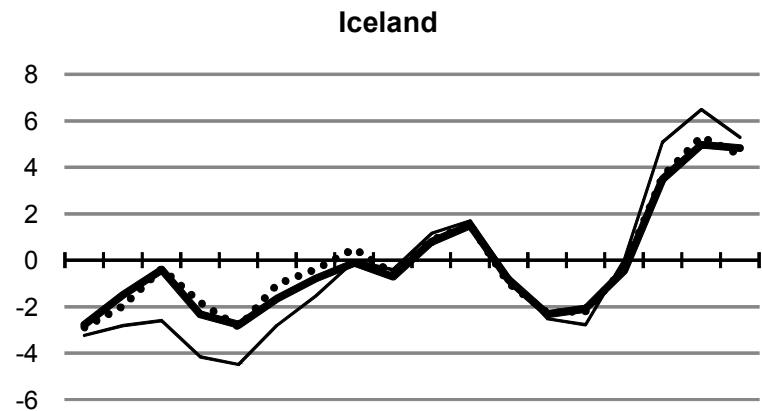

909192939495969798990001020304050607

Korea

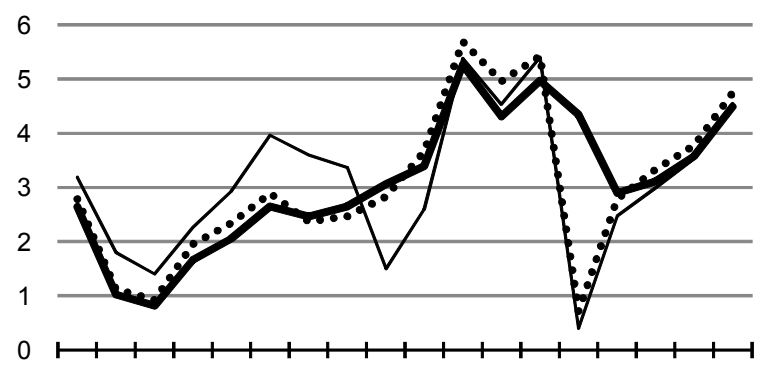

909192939495969798990001020304050607

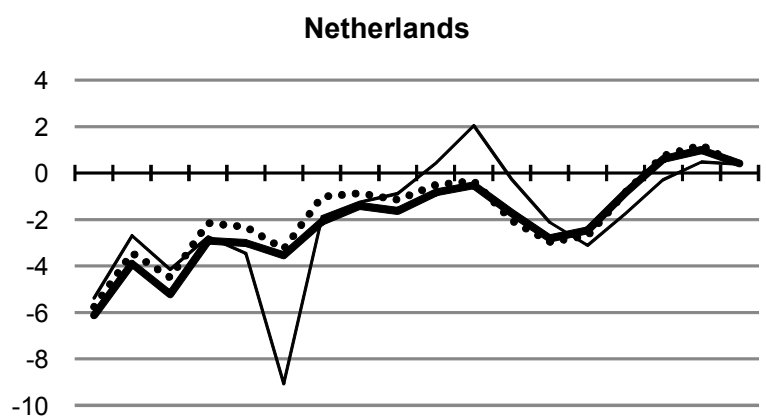

909192939495969798990001020304050607

Headline balance (1)

Cyclically-adjusted balance (1)

Underlying balance

1. Ad-hoc adjustments on one-offs made in the OECD Economic Outlook database up to the 83rd edition have been repealed. Source: OECD Economic Outlook 83 database. 
Figure 4. Headline, cyclically-adjusted and underlying fiscal balances (cont.)

Per cent of potential GDP (different scales)

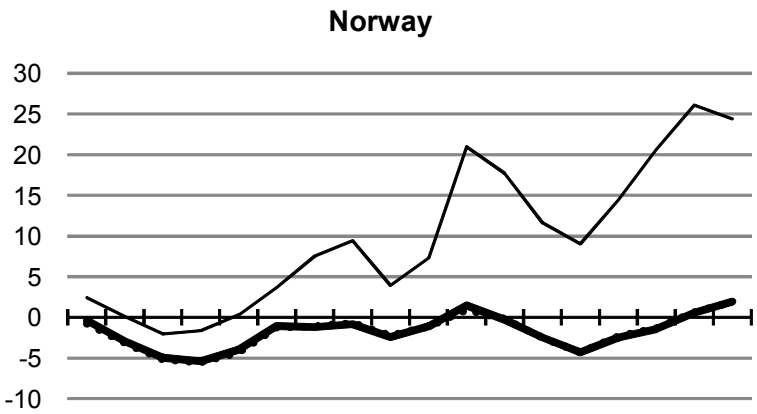

909192939495969798990001020304050607

Portugal

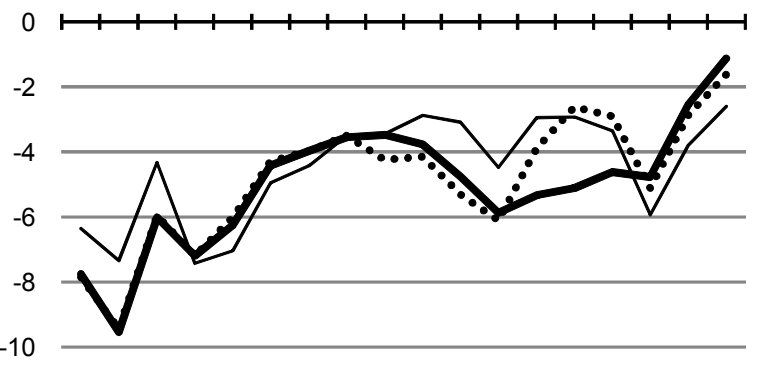

909192939495969798990001020304050607

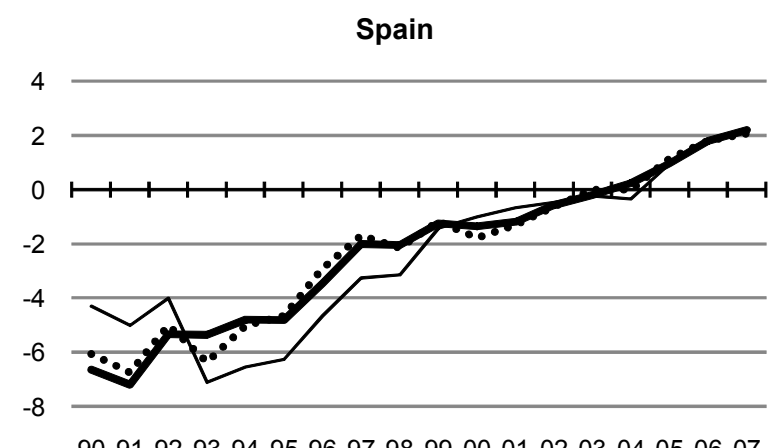

909192939495969798990001020304050607

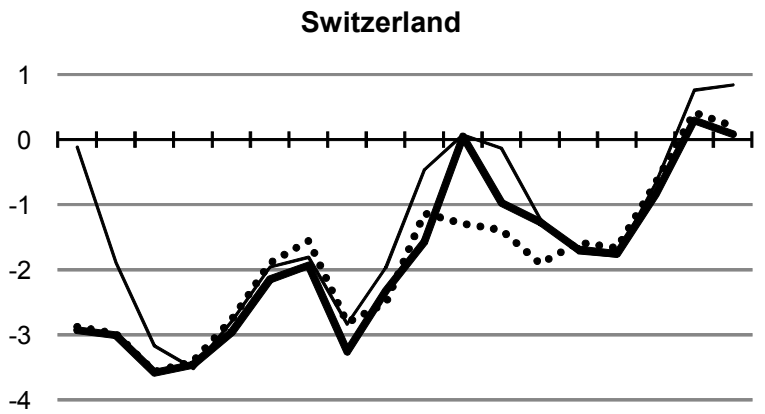

909192939495969798990001020304050607

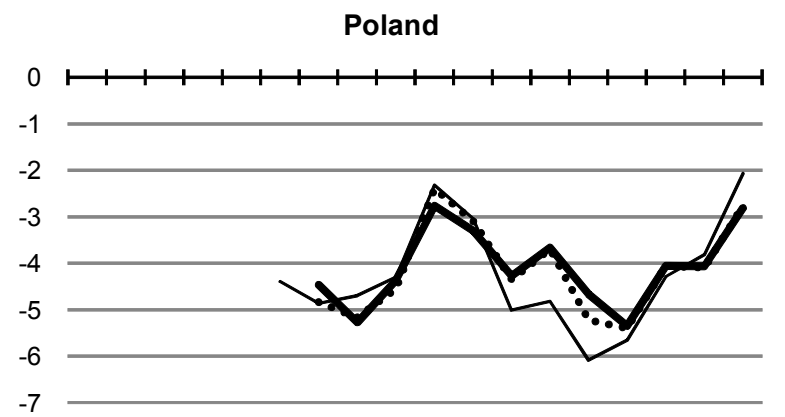

909192939495969798990001020304050607

\section{Slovak Republic}

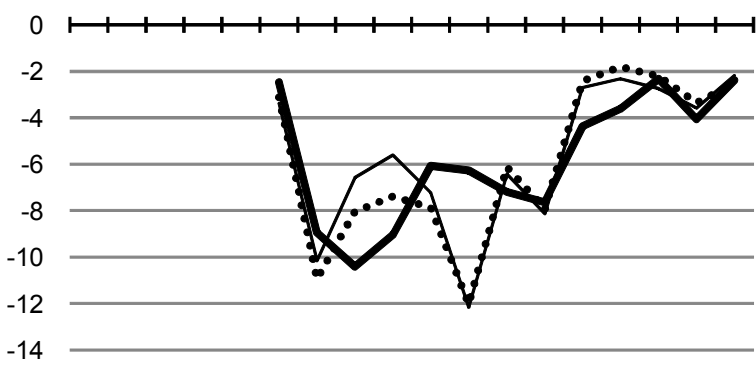

909192939495969798990001020304050607

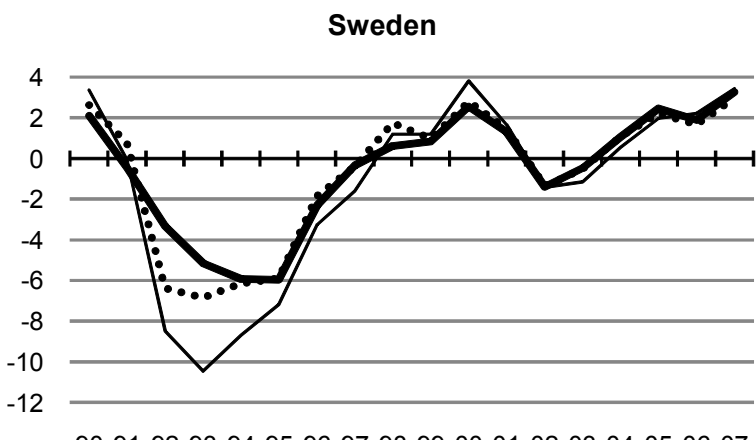

909192939495969798990001020304050607

1. Ad-hoc adjustments on one-offs made in the OECD Economic Outlook database up to the 83rd edition have been repealed. Source: OECD Economic Outlook 83 database. 


\section{$5.3 \quad$ Potential caveats of the proposed approach}

20. There are potential caveats, both conceptual and technical, to the approach presented here. The most obvious one is the focus on capital transfers which leaves out one-off operations not registered as such. The in-depth analysis for nine OECD countries has revealed that such cases are rather limited. Still, some one-offs that are usually classified as capital transfers may be treated differently for some countries, raising a risk of inconsistency. One-off receipts resulting from tax amnesties are a case in point. In most countries (see for instance the Belgian and Italian cases referred to in the Appendix), they are reflected in an increase in capital taxes and will thus be considered as a one-off when applying the HP approach. In contrast, the Portuguese tax amnesty concerning tax and social contribution arrears is reflected in an increase in current taxes and social security contributions for 2001. As this tax amnesty had the very same one-off nature, related revenues should also be excluded from the underlying fiscal balances to maintain consistency. ${ }^{18}$

21. One-off operations may involve capital transfers but be budget neutral when they are matched by other fiscal transactions. A tricky case is the 2005 UK government purchase of nuclear reactors at the end of their productive life whose asset values were negative. It involved a combination of a capital transfer perfectly matched by a reduction in gross fixed capital formation and was thus budget-neutral. For this type of operation, it is misleading to take into account only the capital transfer part. ${ }^{19}$

22. The treatment of sales of real assets (such as buildings and equipments) is more straightforward. Sales of real assets affect fiscal balances through a reduction in "gross capital formation" - they are considered as negative investment - but they leave net capital transfers unchanged. There would seem no compelling reason for treating such sales as one-off items so long as large-scale investment projects (such as public infrastructure projects) are not. Furthermore, OECD national account data even at the most detailed levels do not contain specific data on sales of real assets and information availability from national sources is erratic. Adjusting fiscal indicators for these operations is thus not fully justified or even feasible.

23. The last potential caveat is related to the use of the HP filter to identify the "normal" level of capital transfers. A widely acknowledged problem with the use of HP filters is the end-of-sample problem - derived trends can change as new data are added. In particular, a concentration of large one-offs in the most recent years may have some impact on the HP filter trend, although somewhat rigid smoothing parameter should mitigate this problem. This rigidity may however lead to a lagged recognition in case of a structural change in trend in net capital transfers. In practice, structural changes in net capital transfers are not frequent and, when they occur, their impact on fiscal balances each year tends to be small. Additionally, since any deviation from the HP trend will be taken as proxy of one-offs, underlying balances may also fail to include fluctuations of net capital transfers not caused by one-offs, though that should be analytically acceptable given inherent volatility of net capital transfers. Lastly, a complication also exists regarding how to take account of "repeated" one-off operations that has impact on fiscal balances continuously in the

18. In the Portuguese case, another complication arises from the securitisation of tax and social contribution arrears conducted in 2002. This operation yielded one-off revenues amounting to $0.9 \%$ of potential GDP, which have been recorded as increases in current tax and social contribution receipts. On the other hand, the similar operation for Belgium in 2005 and 2006 has been recorded as capital transfers. In any case, the June 2007 Eurostat ruling stipulates for EU countries that similar transactions conducted after 1 January 2007 should be treated as government borrowing, with no impact on the fiscal balance. The underlying fiscal balances for Portugal shown in Figure 4 have been adjusted for this securitisation as well as for the tax amnesty discussed in the main text.

19. The underlying balance for the United Kingdom shown in Figure 4 has been adjusted for this factor. 
same direction over some years. The HP filter tends to interpret at least a fraction of these repeated one-off operations as a structural change in net capital transfers. ${ }^{20}$

\subsection{Comparing underlying balances with two different approaches for measuring one-offs}

24. The levels and changes of the underlying fiscal balances have both been compared with an alternative measure based on an individual assessment of one-offs for the nine countries covered by the indepth survey. For changes in the underlying fiscal balances, the two different approaches for measuring one-offs lead to very similar results (Figure 5). For levels, too, the two approaches do not lead to noticeable differences.

25. There are a few cases for which the approach based on HP filters produces some discrepancies from cyclically adjusted balances even in the absence of identified one-offs. Two main types of discrepancies emerge from the in-depth study on 9 countries. The first one results from the lagged recognition of changing trends and applies to Germany and the Netherlands in the 1990s. Net capital transfers of these countries show a very gradual upward trend and rigid HP filters have failed to keep up with actual developments. Although a less rigid HP filter could mitigate this problem, it would make the proposed underlying indicator more susceptible to end points. The other type emerges when net capital transfers remain volatile even after adjusting for one-offs - Italy and Portugal are most concerned (see Figure 3). Overall, however, discrepancies between the results of the two approaches are quite limited in magnitude.

\section{Conclusion and overall assessment}

26. One-offs can have a temporary, but large, impact on headline fiscal balances in some countries. They thus require due consideration when assessing fiscal positions. The approach presented in this paper to identify one-offs, based on national account data, would be attractive compared to the alternative based on the individual identification of one-offs in at least two respects. It would ensure better consistency in treatment both across countries and over time. It would also allow a longer time series to be derived for capital transfers adjusted for one-offs and hence for underlying fiscal balances. It suffers some drawbacks, which require that results be interpreted with some caution, but in practice these remain limited (Box 1). Underlying fiscal balances as presented in this paper should be a useful tool in the regular assessment of economic conjunctures.

20. For instance, Japan's fiscal balances both in 2006 and 2007 have been affected by the same positive oneoff operation: a large amount of cash accumulated in the reserves of the Fiscal Loan Special Account has been drawn down. If this operation is to be repeated in 2008 onward, the impact of these one-offs will eventually feed into the HP trend for capital transfers. While these transfers may all be considered as "oneoffs", their repeated nature may actually imply that they reflect some structural effort on the part of the government to streamline overall public sector accounts. 
Figure 5. Comparing underlying balances with two different approaches for measuring one-offs Per cent of potential GDP (different scales)

United States
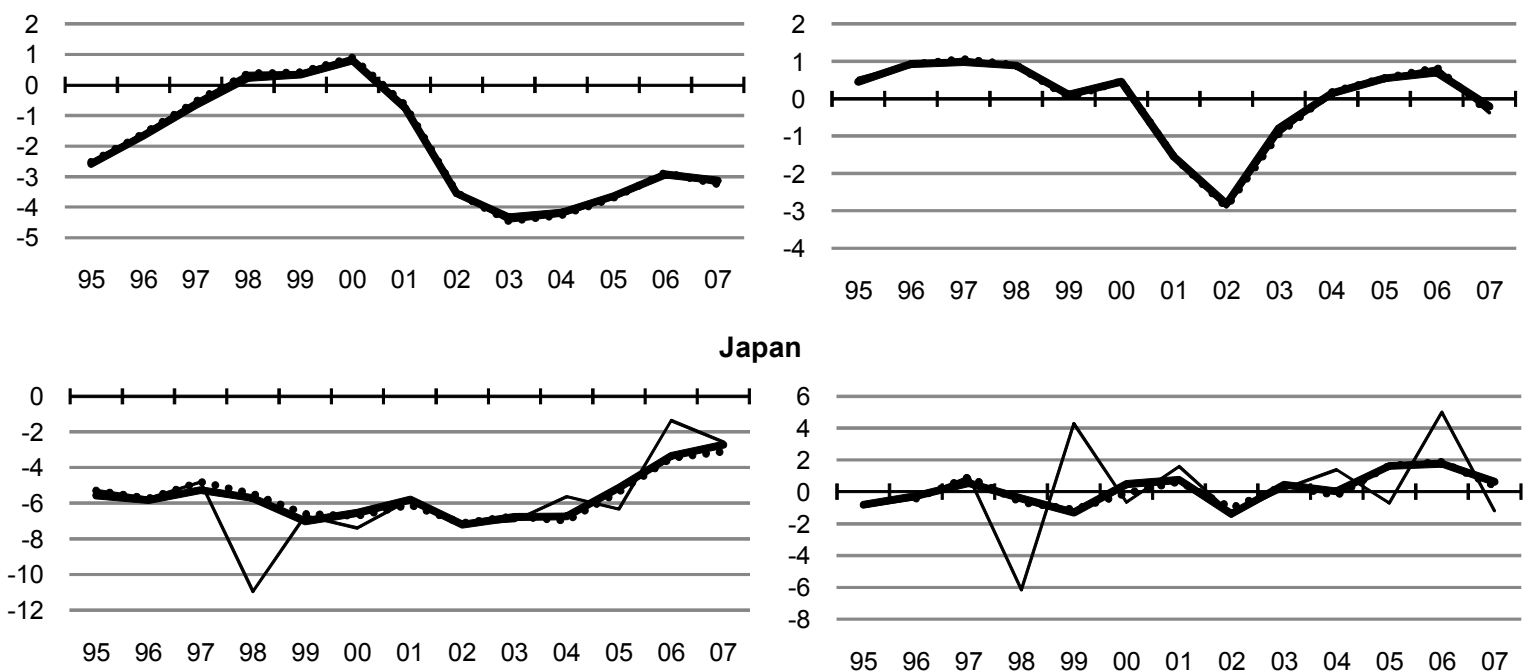

Germany
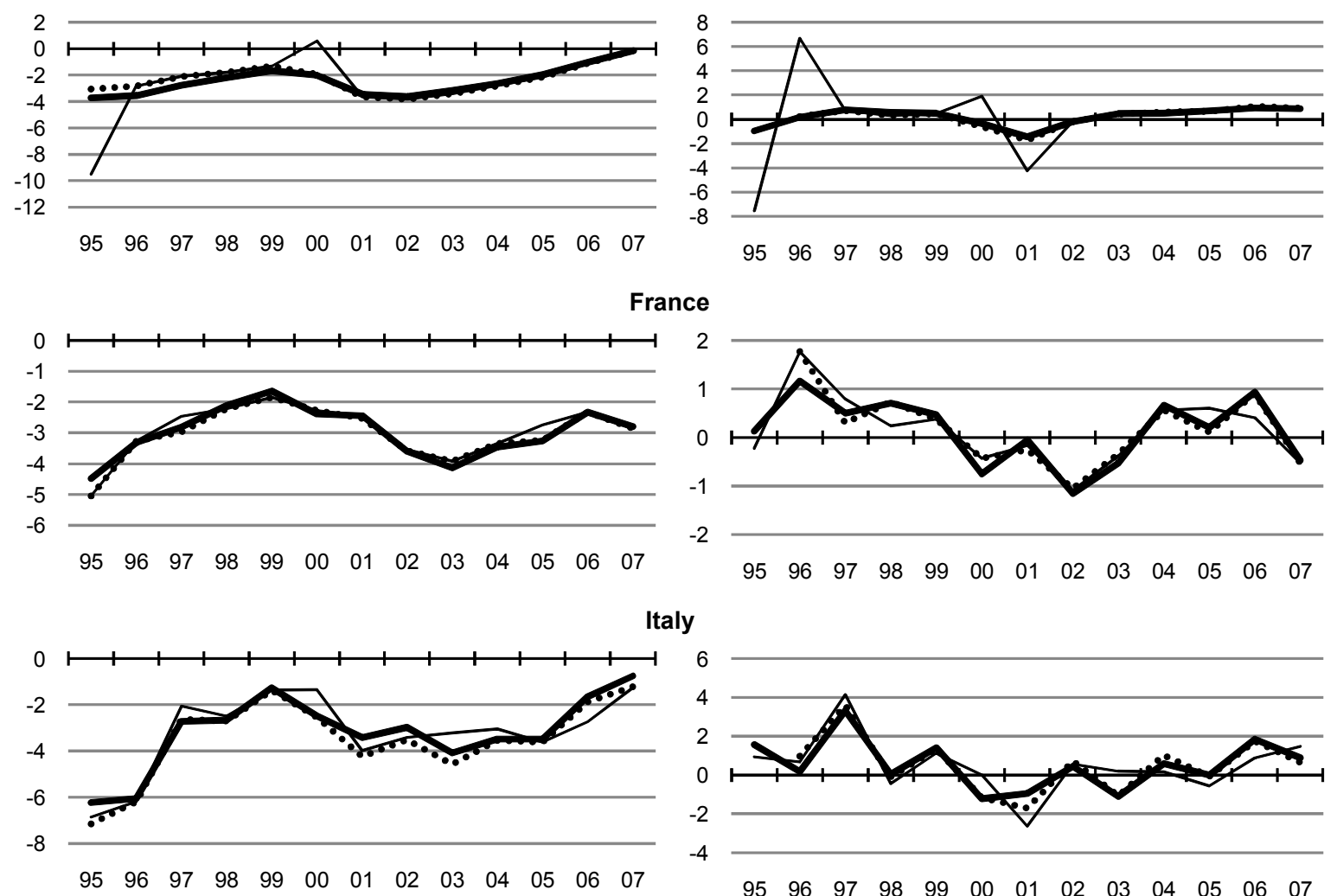

taly

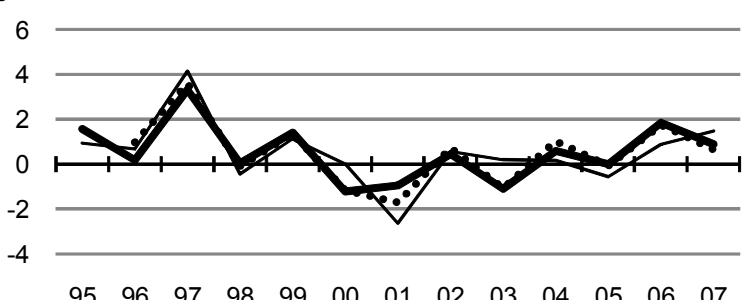

$\begin{array}{lllllllllllll}95 & 96 & 97 & 98 & 99 & 00 & 01 & 02 & 03 & 04 & 05 & 06 & 07\end{array}$

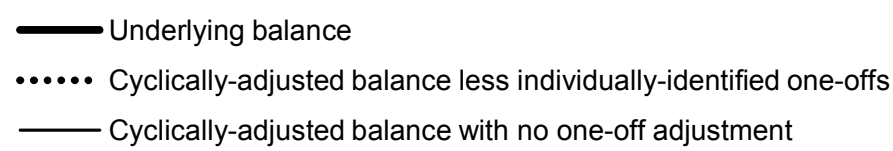

Source : OECD Economic Outlook 83 database and OECD calculations. 


\section{Box 1. Advantages and limitations of the new approach}

The advantages and limitations of the new approach, compared with an approach based on an individual identification of one-offs, are summarised in this Box. While the limitations imply that some caution is required in interpreting the fiscal indicators, the advantages are nonetheless considered to be significant.

\section{Advantages:}

- The systematic identification of one-offs embodied in the method ensures consistency in treatment both across countries and over time, even in the absence or incompleteness of information on one-off operations.

- The method successfully accounts for most one-offs. One-offs identified with the HP filter method are very close to one-offs identified individually or by the EC. ${ }^{1}$

- $\quad$ Series for underlying fiscal balances can be derived over reasonably long periods of time and for most OECD countries.

- Ex post revisions to the fiscal impacts of one-off operations are automatically accounted for as soon as national accounts data are revised (whereas the itemised approach does not usually correct ex ante estimates of one-offs).

\section{Limitations:}

- By construction, the approach leaves out one-offs that are not registered as capital transfers. But in practice, the vast majority of one-offs are registered as capital transfers and the others can be treated individually (when information is available).

- The use of the HP filter raises an end-of-sample problem - one-offs identified being potentially dependent to net capital transfer data at the end of the sample period - though the application of a rather rigid filter substantially mitigates this problem.

- Net capital transfers may include volatile components which are not necessarily one-offs. They will be excluded from the underlying fiscal balances derived with an HP filter. This may not be too problematic since these volatile components may hardly be seen as structural or underlying. However, a temporary bias in the estimation of underlying fiscal balances could occur where structural changes in net capital transfer trends are not recognised. In practice, structural changes in net capital transfers are not frequent and, when they occur, their impact tends to be small.

Note:

1. Comparing the OECD estimates with the EC measures of one-offs, as presented in Public Finances in EMU, reveals only minor differences. A notable exception exists for Italy for which asset sales have been important. While sales of real assets have been considered as a "one-off" operation by the EC, they have not been adjusted for in the underlying balances. This explains a large part of the difference for Italy. Some additional adjustments have also been made for Portugal and the United Kingdom to maintain consistency as discussed above. 


\section{BIBLIOGRAPHY}

Besnard, D. and L. Paul (2004a), "One-off Budgetary Measures and Government Deficits", Banque de France Bulletin Digest, No. 128, August.

Besnard, D. and L. Paul (2004b), "One-off Budgetary Measures", Banque de France Bulletin Digest, No. 129, September.

Blanchard, O. (1990), "Suggestions for a New Set of Fiscal Indicators", OECD Department of Economics and Statistics Working Paper No. 79, OECD, Paris.

Chouraqui, J-C, R. Hagemann and N. Sartor (1990), "Indicators of Fiscal Policy: a Re-examination", OECD Economics Department Working Paper No. 78, OECD, Paris.

Congressional Budget Office (2007), The Cyclically Adjusted and Standardized Budget Measures: An Update, August.

Doihara, H, K. Masabuchi, M. Maruyama and S. Hasegawa (2006), "Recent Developments of the Japanese Economy Seen from the National Accounts", ESRI Discussion Paper Series, No. 167, Cabinet Office, Tokyo, Japan, July.

European Commission (EC) (2006), Public Finances in EMU, Brussels.

Eurostat (2002), ESA 95 Manual on Government Deficit and Debt.

Girouard, N. and C. André (2005), "Measuring Cyclically Adjusted Budget for OECD Countries", OECD Economics Department Working Papers, No. 434, OECD, Paris.

Girouard, N. and R. Price (2004), “Asset Price Cycles, 'One-off' Factors and Structural Budget Balances”, OECD Economics Department Working Papers, No. 391, OECD, Paris.

Koen, V. and P. van den Noord (2005), "Fiscal Gimmickry in Europe: One-off Measures and Creative Accounting", OECD Economics Department Working Papers, No. 417, OECD, Paris.

Milesi-Ferretti G.M. and K. Moriyama (2004), "Fiscal Adjustment in EU Countries: A Balance Sheet Approach", IMF Working Paper WP/04/143.

OECD (2005), Economic Surveys: Italy, OECD, Paris.

OECD (2008), OECD Economic Outlook, Vol. 2008/1, No. 83, June, OECD, Paris.

Price, R and P. Muller (1984), "Structural Budget Indicators and the Interpretation of Fiscal Stance in OECD economies", OECD Economic Studies, Vol. 3, OECD, Paris.

Turner, D. (2006), "Should Measures of Fiscal Stance be Adjusted for Terms of Trade Effects?", OECD Economics Department Working Papers, No. 519, OECD, Paris.

United Nations (2001), 1993 SNA on the web (http://unstats.un.org/unsd/sna1993/toctop.asp ). 


\section{APPENDIX: \\ ONE-OFFS IDENTIFIED IN THIS PAPER}

An in-depth examination of one-off operations has been carried out for nine OECD countries Belgium, France, Germany, Japan, Italy, the Netherlands, Portugal, the United Kingdom and the United States, from 1995 onward to 2007. Box 2 describes the sources used to identify the one-offs in these countries. Information on one-offs by individual country is presented below.

\section{Box 2. Data and sources used to identify one-offs}

Japan

Cabinet Office of the Government of Japan, Annual Report on National Accounts, Economic and Social Research Institute, various issues.

Doihara, H., K. Masabuchi, M. Maruyama and S. Hasegawa (2006), "Recent Developments of the Japanese Economy Seen from the National Accounts", ESRI Discussion Paper Series, No. 167, Cabinet Office, Tokyo, Japan, July.

IMF, Japan: Article IV Consultation - Staff Report, various issues.

Sources common to European countries

European Commission, Public Finance in EMU, various issues.

Eurostat, News Release, various issues.

Koen, V. and P. van den Noord (2005), "Fiscal Gimmickry in Europe: one-off measures and creative accounting", OECD Economics Department Working Papers, No. 417.

Girouard, N. and R. Price (2004), "Asset Price Cycles, 'One-off' Factors and Structural Budget Balances”, OECD Economics Department Working Papers, No. 391.

France

Schalck, L. (2007), "Transfers to the Government of Public Corporation Pension Liabilities: The French Case Study", Temporary Measures and Off-budget Activities, MNB Public Finance Workshop.

Italy

Banca d'Italia, Economic Bulletin, various issues.

Momigliano-Pietro, S (2007), "Temporary Measures in Italy: Buying or Losing Time?", Temporary Measures and Off-budget Activities, MNB Public Finance Workshop.

\section{United Kingdom}

National Statistics (2006), Press Release (http://www.statistics.gov.uk/pdfdir/bi1206.pdf), December.

\section{Belgium}

National Bank of Belgium, Annual Report, various issues.

OECD, Economic Surveys: Belgium, Paris, various issues.

Netherlands

OECD, Economic Surveys: Netherlands, Paris, various issues.

Portugal

Banco de Portugal, Annual Report, various issues.

Banco de Portugal, Economic bulletin, various issues.

Eurostat (2006), EDP dialogue visit to Portugal, March.. 


\begin{tabular}{|c|c|c|}
\hline \multicolumn{3}{|c|}{ Belgium } \\
\hline Year & Fiscal operations & Size \\
\hline 2001 & UMTS licence receipt & $+0.2 \%$ \\
\hline 2003 & $\begin{array}{l}\text { Up-front payment receipt in exchange for transfer of pension obligation (Belgacom) } \\
\text { Shift in the timing of investment grants to SNCB } \\
\text { Debt assumption (Antwerp hospital) }\end{array}$ & $\begin{array}{l}+1.8 \% \\
-0.4 \% \\
-0.1 \%\end{array}$ \\
\hline 2004 & Shift in the timing of investment grants to SNCB & $+0.4 \%$ \\
\hline & Up-front payment receipt in exchange for transfer of pension obligation (Biac) & $+0.1 \%$ \\
\hline & Fiscal securitisation (tax amnesty) & $+0.2 \%$ \\
\hline 2005 & $\begin{array}{l}\text { Up-front payment receipt in exchange for transfer of pension obligation (SNCB and Antwerp } \\
\text { Port Authority) }\end{array}$ & $+0.2 \%$ \\
\hline & Securitisation of tax arrears & $+0.1 \%$ \\
\hline & VAT ruling (Aquafin) & $+0.1 \%$ \\
\hline & Debt assumption (SNCB, in line with Eurostat decision) & $-2.4 \%$ \\
\hline 2006 & Securitisation of tax arrears & $+0.1 \%$ \\
\hline \multicolumn{3}{|c|}{ France } \\
\hline 1995 & Up-front payment receipt in exchange for transfer of pension obligation (France Télécom) & $+0.5 \%$ \\
\hline 2001 & UMTS licence receipt & $+0.1 \%$ \\
\hline 2005 & Up-front payment receipt in exchange for transfer of pension obligation (EdF and GdF) & $+0.5 \%$ \\
\hline \multicolumn{3}{|c|}{ Germany } \\
\hline 1995 & Debt assumption (the Inherited Fund) & $-6.5 \%$ \\
\hline 2000 & UMTS licence receipt & $+2.5 \%$ \\
\hline \multicolumn{3}{|c|}{ Italy } \\
\hline 1995 & Tax amnesty & $+0.3 \%$ \\
\hline 1997 & Special capital tax (“Eurotax") & $+0.6 \%$ \\
\hline 1998 & Special levy on severance pay provisions & $+0.2 \%$ \\
\hline 2000 & UMTS licence receipt & $+1.2 \%$ \\
\hline 2001 & $\begin{array}{l}\text { Temporary effects from changes in capital gains tax (elimination of possibility to pay liabilities } \\
\text { in instalments) }\end{array}$ & $+0.3 \%$ \\
\hline 2002 & Tax amnesty & $+0.1 \%$ \\
\hline 2003 & Tax amnesty & $+1.4 \%$ \\
\hline 2004 & Tax amnesty & $+0.5 \%$ \\
\hline 2006 & Debt cancellation (High-speed train project) & $-0.9 \%$ \\
\hline 2007 & VAT refund (ECJ ruling) & $-0.1 \%$ \\
\hline \multicolumn{3}{|c|}{ Japan } \\
\hline \multirow[t]{2}{*}{1998} & $\begin{array}{l}\text { Debt assumptions (the Japan National Railway Settlement Corporation and the National Forest } \\
\text { Special Account) }\end{array}$ & $-5.3 \%$ \\
\hline & Capital injection to Deposit Insurance Corporation & $-0.2 \%$ \\
\hline 1999 & Capital injection to Deposit Insurance Corporation & $-0.1 \%$ \\
\hline \multirow[t]{2}{*}{2000} & Capital injection to Deposit Insurance Corporation & $-1.2 \%$ \\
\hline & Deferred tax payments on postal savings accounts & $+0.5 \%$ \\
\hline \multirow[t]{2}{*}{2001} & Capital injection to Deposit Insurance Corporation & $-0.3 \%$ \\
\hline & Deferred tax payments on postal savings accounts & $+0.6 \%$ \\
\hline \multirow[t]{2}{*}{2002} & Capital injection to Deposit Insurance Corporation & $-0.2 \%$ \\
\hline & Deferred tax payments on postal savings accounts & $+0.1 \%$ \\
\hline \multirow[t]{3}{*}{2003} & Partial debt cancellation (Honshu-Shikoku Bridge Authority) & $-0.3 \%$ \\
\hline & Capital injection to Deposit Insurance Corporation & $-0.1 \%$ \\
\hline & Transfer back to the government of the basic part of the corporate pension scheme & $+0.1 \%$ \\
\hline 2004 & Transfer back to the government of the basic part of the corporate pension scheme & $+1.4 \%$ \\
\hline 2005 & $\begin{array}{l}\text { Transfer back to the government of the basic part of the corporate pension scheme } \\
\text { Purchase of lands related to highway privatisation }\end{array}$ & $\begin{array}{l}+0.8 \% \\
-1.8 \%\end{array}$ \\
\hline \multirow[t]{2}{*}{2006} & Transfer back to the government of the basic part of the corporate pension scheme & $+0.3 \%$ \\
\hline & Special payment from reserve fund of the Fiscal Loan Fund Special Account & $+1.8 \%$ \\
\hline 2007 & Special payment from reserve fund of the Fiscal Loan Fund Special Account & $+0.6 \%$ \\
\hline
\end{tabular}


ECO/WKP(2008)50

\begin{tabular}{|c|c|c|}
\hline \multicolumn{3}{|c|}{ Netherlands } \\
\hline Year & Fiscal operations & Size \\
\hline 1995 & Exceptional capital injection to the social rental company & $-4.8 \%$ \\
\hline 1996 & Court decision regarding natural gas receipt (dispute over so-called "Common Area") & $+0.2 \%$ \\
\hline 1997 & Court decision regarding natural gas receipt (dispute over so-called "Common Area") & $+0.1 \%$ \\
\hline 2000 & UMTS licence receipt & $+0.7 \%$ \\
\hline 2001 & Purchase of gas rights from DSM & $-0.3 \%$ \\
\hline \multicolumn{3}{|c|}{ Portugal } \\
\hline 1997 & $\begin{array}{l}\text { Up-front payment receipt in exchange for transfer of pension obligation (Banco Nacional } \\
\text { Ultramarino) }\end{array}$ & $+0.4 \%$ \\
\hline 2000 & UMTS licence receipt & $+0.4 \%$ \\
\hline \multirow[t]{2}{*}{2002} & Sale of future toll rights & $+0.2 \%$ \\
\hline & Tax amnesties (on tax and social contribution arrears) & $+0.9 \%$ \\
\hline \multirow[t]{3}{*}{2003} & Tax amnesties (on tax and social contribution arrears) & $+0.1 \%$ \\
\hline & Up-front payment receipt in exchange for transfer of pension obligation (CTT <Post Office>) & $+0.9 \%$ \\
\hline & Securitisation of tax and social contribution arrears & $+1.3 \%$ \\
\hline 2004 & Up-front payment receipt in exchange for transfer of pension obligation (CGD <a bank> etc) & $+2.1 \%$ \\
\hline \multicolumn{3}{|c|}{ United Kingdom } \\
\hline 2000 & UMTS licence receipt & $+2.4 \%$ \\
\hline \multirow[t]{2}{*}{2005} & Transfer of nuclear reactors (the part affecting net capital transfers) & $-1.3 \%$ \\
\hline & Transfer of nuclear reactors (the part affecting gross capital formation) & $+1.3 \%$ \\
\hline \multicolumn{3}{|c|}{ United States } \\
\hline
\end{tabular}

Notes:

1. The identification of one-off operations listed above has been made based on available information through various sources (national governments, central banks, OECD, IMF, EC, etc.), as discussed in Box 2. It should not, however, be taken as an exhaustive list of one-off factors.

2. All figures are expressed as percentages of potential GDP. A positive sign indicates a balance-improving effect, while a negative sign shows a balance-deteriorating effect.

3. Shaded areas indicate one-off operations that are classified as net capital transfers. 
ECO/WKP(2008)50

\section{WORKING PAPERS}

The full series of Economics Department Working Papers can be consulted at www.oecd.org/eco/Working_Papers/

641. Do corporate taxes reduce productivity and investment at the firm level? Cross-country evidence from the Amadeus dataset

(October 2008) Cyrille Schwellnus and Jens Arnold

640. The challenge of rapidly improving transport infrastructure in Poland

(September 2008) Rafal Kierzenkowski

639. Bridging the housing gap in Poland

(September 2008), Rafal Kierzenkowski

638. Improving the business and investment climate in Indonesia

(September 2008), Diego Moccero

637. Growth performance and policy challenges

(September 2008), Luiz de Mello

636. A taxonomy of instruments to reduce greenhouse gas emissions and their interactions (September 2008), Romain Duval

635. Quantifying the effect of financial conditions on US activity (September 2008) Stéphanie Guichard and David Turner

634. Have long-term financial trends changed the transmission of monetary policy (September 2008), Stéphanie Guichard and David Turner

633. Raising education achievement and breaking the cycle of inequality in the United Kingdom (August 2008) Anne-Marie Brook

632. The euro changeover in the Slovak Republic: implications for inflation and interest rates (August 2008) Felix Hüfner and Isabell Koske

631. Tax reform for efficiency and fairness in Canada (August 2008) Alexandra Bibbee

630. Reforming the Polish Tax System to Improve its Efficiency (August 2008) Alain de Serres

629. Modernising Canada's Agriculture Policies (August 2008) Peter Jarrett and Shuji Kobayakawa

628. Recent trends and structural breaks in US and EU15 labour productivity growth (August 2008) Laure Turner and Hervé Boulhol

627. Health Status Determinants: Lifestyle, Enviroment, Health Care Resources and Efficiency (August 2008) Isabelle Joumard, Christophe André, Chantal Nicq and Olivier Chatal 
626. Market Mechanisms in Public Service Provision (August 2008) Hansjörg Blöchliger

625. Improving human capital formation in India (July 2008) Sean M. Dougherty and Richard Herd

624. Labour regulation and employment dynamics at the state level in India (July 2008) Sean M. Dougherty

623. India's growth pattern and obstacles to higher growth (July 2008) Sean M. Dougherty, Richard. Herd, Thomas. Chalaux and Abdul. Erumban

622. Reaping the benefits of stronger competition in network industries in Germany (July 2008) Nicola Brandt

621. The Usefulness of Output Gaps for Policy Analysis (July 2008) Isabell Koske and Nigel Pain

620. Taxation and Economic Growth (July 2008) Åsa Johansson, Christopher Heady, Jens Arnold, Bert Brys and Laura Vartia

619. Coping with labour shortages: How to bring outsiders back to the labour market (July 2008) Ekkehard Ernst

618. Achieving sustainability of the energy sector in Canada (June 2008) Annabelle Mourougane

617. The Dutch tax-benefit system and life-cycle employment. Outcomes and reform options (June 2008) Ekkehard Ernst and Timo Teuber

616. Regulation, Allocative Efficiency and Productivity in OECD Countries: Industry and Firm-Level Evidence (May 2008) Jens Arnold, Giuseppe. Nicoletti, and Stefano Scarpetta

615. Public social spending in Korea in the context of rapid population ageing (May 2008) Randall S. Jones

614. Enhancing the globalisation of Korea (May 2008) Randall S. Jones and Taesik Yoon

613. Reforming housing and regional policies in Korea (May 2008) Randall S. Jones and Tadashi Yokoyama

612. Moving towards more sustainable healthcare financing in Germany (May 2008) N. Brandt

611. Improving education outcomes in Germany (May 2008) David Carey

610. Have developed countries escaped the curse of distance? (May 2008) Hervé Boulhol and Alain de Serres 